P-ISSN: 2774-4574; E-ISSN: 2774-4582

TRILOGI, 1(2), Sept-Des 2020 (16-34)

@2020 Lembaga Penerbitan, Penelitian, dan Pengabdian kepada Masyarakat (LP3M)

Universitas Nurul Jadid Paiton Probolinggo

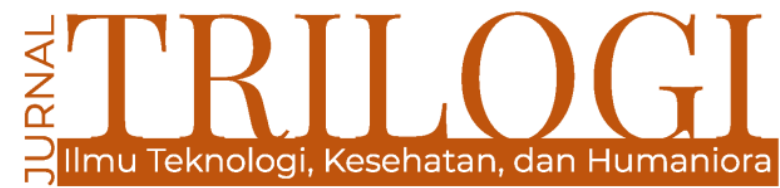

DOI: https://doi.org/

\title{
PEMANFAATAN TEKNOLOGI UNTUK DESA: E-Village Berbasis Web Menggunakan Framework CodeIgniter di Kantor Desa Pesisir Besuki
}

\author{
Eko Purnomo \\ Universitas Nurul Jadid Probolinggo, Indonesia \\ eko.purnomo@unuja.ac.id \\ Nur Diana \\ Universitas Nurul Jadid Probolinggo, Indonesia \\ nurdianafitriyah17@gmail.com
}

\begin{abstract}
The $3 \mathrm{M}$ protocol (washing hands, wearing masks and keeping a distance) makes community services that interact directly with the community must be limited. The creation of a Web-based E-village is intended to assist in improving village community services, namely services related to writing letters and information about villages, especially during the Covid-19 pandemic. E-viilage is a web-based application developed using an open source application, namely the Codeigniter framework with the MVC model (Model View and Control). The method of research and system development in this study uses the Waterfall model which includes needs analysis, system design, writing program code, program testing, program implementation and maintenance. This application was built using Visual Studio Code with PHP programming language and Codeigniter Framework and supported by MySQL Database. The conculsion of this study are: (1) Web-based E-village application has been produced at the Pesisir Besuki Village Office. (2) This application can help and facilitate community service, namely writing services at the Pesisir Besuki Village Office, from external test results with proper status an $79.2 \%$
\end{abstract}

Keywords: E-Village; Website; Codeigniter

\section{Abstrak}

Protokol 3M (Mencuci tangan, Memakai masker dan Menjaga jarak) membuat pelayanan masyarakat yang berinteraksi langsung dengan masyarakat harus dibatasi. Pembuatan E-village Berbasis Web ditujukan untuk membantu dalam meningkatkan pelayanan masyarakat desa yaitu pelayanan terkait pembuatan surat dan informasi tentang desa terutama pada masa pandemic Covid-19. Selain bermanfaat bagi masyarakat tentunya ini juga sangat bermanfaat bagi aparatur desa dalam manajemen adminstrasi desa. E-viilage ini merupakan aplikasi berbasis web yang dikembangkan menggunakan aplikasi open source yaitu framework Codeigniter dengan model MVC (Model View dan Control. Metode penelitian dan pengembangan sistem dalam penelitian ini menggunakan model Waterfall yang meliputi analisis kebutuhan, desain sistem, penulisan kode program, pengujian program atau testing, penerapan program dan pemeliharaan. Untuk perancangan alur sistem menggunakan flowchart, Data flow diagram (DFD), dan Entity Relationship Diagram (ERD). Aplikasi ini dibangun menggunakan Visual Studio Code dengan bahasa pemograman PHP dan Framework Codeigniter serta didukung dengan Database MySQL. Maka kesimpulan dari penelitian ini yaitu : (1) Telah dihasilkan aplikasi E-village Berbasis Web di Kantor Desa Pesisir Besuki.( 2) Aplikasi ini dapat membantu dan mempermudah dalam pelayanan masyarakat yaitu pelayanan pembuatan surat di Kantor Desa Pesisir Besuki, hal ini dibuktikan dari hasil pengujian eksternal dengan status kelayakan $79,2 \%$.

Katakunci: E-Village; Website; Codeigniter 


\section{Pendahuluan}

Kemajuan teknologi yang sangat pesat mendorong setiap pemerintah desa untuk tetap mengikuti perkembangan teknologi dan terus meningkatkan kemampuan dalam mengelola data-data dan informasi yang dimiliki agar lebih akurat dan efisien (Putri, 2019). Pelayanan publik merupakan salah satu tugas penting pemerintah desa untuk memenuhi kebutuhan dan keinginan masyarakat dengan tujuan untuk meningkatkan kesejahteraan masyarakat. Pelayanan publik dapat dikategorikan efektif apabila masyarakat mendapatkan kemudahan pelayanan dengan prosedur yang singkat, cepat, tepat dan memuaskan. Keberhasilan meningkatkan efektifitas pelayanan umum ditentukan oleh factor kemampuan pemerintah dalam meningkatkan disiplin kerja staff desa. Salah satu tugas Aparatur desa atau staf berwenang dalam mengurusi administrasi masyarakat seperti regristasi kartu keluarga $(\mathrm{KK})$, akta kelahiran, dan surat keterangan.

Pelayanan administrasi surat yang ada di kantor Desa umumnya masih dilakukan secara konvensional. Masyarakat yang ingin mengajukan permohonan surat keterangan harus datang langsung dan mengikuti proses yang ada. Hal ini menyebabkan proses dan pelayanannya kurang efisien karena membutuhkan waktu yang lebih lama. Di era perkembangan teknologi saat ini proses yang dilakukan secara konvensional dapat digantikan dengan teknologi yang ada sehingga dapat meningkatkan pelayanan dan produktifitas masyarakat. Proses pelayanan pengajuan permohonan surat keterangan dapat ditingkatkan dengan mengunakan teknologi informasi yaitu aplikasi berbasis Web.

Aplikasi berbasis web/wibesite yang diakes secara online dapat menghubungkan antara petugas dan masyarakat secara tidak langsung dan meminimalisir durasi tatap muka atau tanpa harus bertemu langsung sehingga masyarkat dapat melakukan aktifitas yang lain sembari menunggu proses pangajuan selesai. Peningkatan pelayanan dengan menerapkan tekonologi berbasis web sudah selaras dengan aktifitas masyarakat dalam menggunakan smartphone dan internet. Persentase penduduk yang menggunakan telepon selular terus mengalami peningkatan, hingga pada tahun
2018 mencapai 62,41 persen. Pertumbuhan penggunaan telepon selular ini diikuti pula oleh pertumbuhan kepemilikan komputer dan kepemilikan akses internet dalam rumah tangga yang mencapai angka 20,05 persen untuk kepemilikan komputer dan 66,22 persen untuk kepemilikan akses internet dalam rumah tangga. Penggunaan internet juga mengalami peningkatan selama kurun waktu 2014-2018, yang ditunjukkan dari meningkatnya persentase penduduk yang mengakses internet pada tahun 2014 sekitar 17,14 persen menjadi 39,90 persen pada tahun 2018 (BPS, 2018). Hal ini menunjukan bahwa diterapkannya aplikasi pelayanan berbasis web sudah tidak asing dan tidak menjadi kendala bagi masyarakat.

Di kantor Desa Pesisir kecamatan Besuki Kabupaten Situbondo, proses pengajuan surat keterangan sering terjadi kesalahan. Salah satunya adalah masyarakat membuat format surat yang tidak sesuai dengan yang sudah ditentukan dari Kantor Desa. Pelayanan administrasi surat di kantor Desa Pesisir Besuki masih dilakukan secara konvensional. Masyarakat yang ingin mengajukan permohonan surat harus datang, mengantri dan menunggu surat selesai dibuat di kantor desa. Hal ini menyebabkan proses dan pelayanannya kurang efisien karena membutuhkan waktu yang lebih lama.

Peran penting website desa terbukti telah banyak memberi manfaat bagi aparatur desa. Penelitian yang dilakukan oleh Andri Kurniawan, Martha Suhardiyah, dan Amir Nur Hidayat (2019) menyatakan bahwa permasalahan di Desa Karangkuten membutuhkan adanya media informasi sebagai sarana promosi dan informasi desa. Penelitian ini menghasilkan sistem informasi geografis tentang lokasi Desa Karangkuten dan potensi desa. Sistem ini berbasis web dimana pengunjung website dapat mengetahui letak dan luas desa, informasi desa serta potensi dalam desa, sehingga Desa Karangkuten dapat dikenal oleh masyarakat luas. Sedangkan bagi masyarakat Desa Karangkuten sendiri, web ini dapat memudahkan penduduk disana untuk mendapatkan informasi desa. (Kurniawan, Suhardiyah, \& Hidayat, 2019)

Penelitian lain oleh Lukmanul Hakim (2019) menyatakan bahwa permasalahan yang 
ada di desa Pecalongan, Kabupaten Bondowoso saat ini lamanya waktu untuk mencari data yang diarsipkan menggunakan kertas. Data yang dicari terkadang kertasnya sudah rusak dan bahkan ada yang hilang karena data belum tersimpan dalam sistem yang terpusat. Selain itu, dalam hal pelayanan terhadap masyarakat desa Pecalongan masih menganut sistem konvesional. Sehingga pelayanan di kantor desa memerlukan waktu yang relatif lama dan kurang maksimal. Penelitian ini menghasilkan Sistem Informasi Layanan Desa Berbasis web. Sistem ini dapat membantu petugas dan masyarakat desa dalam hal pelayanan seperti pelayanan surat penduduk. Sistem ini dirancang dan dibangun menggunakan bahasa pemrograman PHP dan MySQL. (Hakim, 2019)

Sementara itu, penelitian oleh Sismadi dan Rame Santoso (2018) menyatakan bahwa permasalahan dalam pengolahan data penduduk di desa cilebut menggunakan komputer namun belum terintegrasi dalam database. Sedangkan data kependudukan yang dikelola memiliki intensitas tinggi mencapai 18,317 jiwa, sehingga menyulitkan dalam pengelolaannya. Penelitian ini menghasilkan Sistem Pengolahan Data Penduduk yang berguna bagi petugas pemerintahan desa cilebut dalam pengolahan data penduduk dan pelayanan masyarakat. Pelayanan tersebut antara lain meliputi pendaftaran penduduk, pindah domisili, kelahiran, kematian dan lainlain. Bahasa pemograman yang digunakan adalah framework codeigniter dan PHP, MYSQL sebagai databasenya. (Sismadi \& Santoso., 2019)

Penelitian-penelitian sebelumnya hanya berfokus pada satu menu saja tetapi manfaat yang dihasilkan sama. Yang menjadi pembeda yakni e-village berbasis web ini mencangkup semua menu yang ada pada penelitian sebelumnya. Seperti fitur pelayanan surat, informasi desa, dan pengolahan data penduduk.

Selain itu, di masa pandemic Covid-19 saat ini pemerintah menghimbau untuk menerapkan protocol kesehatan yaitu 3M, (Mencuci tangan, Memakai masker dan Menjaga jarak) sehingga membuat pelayanan masyarakat yang berinteraksi langsung dengan masyarakat harus dibatasi. Dibangunnya aplikasi ini secara tidak langsung dapat mendukung program pemerintah dalam mengurangi potensi penyebaran Covid-19.
Dari latar belakang masalah yang telah diuraikan sebelumnya, maka dilakukan penelitian ini dengan mengambil judul "Evillage Berbasis Web Menggunakan Framework CodeIgniter Di Kantor Desa" studi kasus Desa Pesisir Besuki Kab Situbondo.

Sistem ini dapat melayani administrasi permohonan surat secara online maupun secara langsung, sehingga akan sangat memudahkan masyarakat. Surat online tersebut meliputi: surat keterangan usaha, surat keterangan umum, dan surat keterangan beda nama. Pembuatan aplikasi ini menggunakan Framework CodeIgniter. Framework Codeigniter adalah aplikasi open source yang berupa framework dengan model MVC (Model, View, and Controller) untuk membangun website dinamis dengan menggunakan PHP. (Supardi \& Hermawan)

Tujuan penelitian ini, khususnya, bagi Kantor Desa Pesisir Besuki adalah embantu petugas dalam melayani administrasi permohonan surat secara online maupun secara langsung dan memudahkan petugas dalam penyajian data penduduk dan informasi terkait desa. Sementara itu, bagi masyarakat secara umum, penelitian ini memudahkan untuk melakukan permohonan surat secara online melalui website yang sudah disediakan oleh pihak Kantor Desa Pesisir Besuki.

\section{Metode}

Alar rancangan penelitian pada pengembangan aplikasi berbasis web dengan menggunakan framework CodeIgniter adalah sebagai berikut:

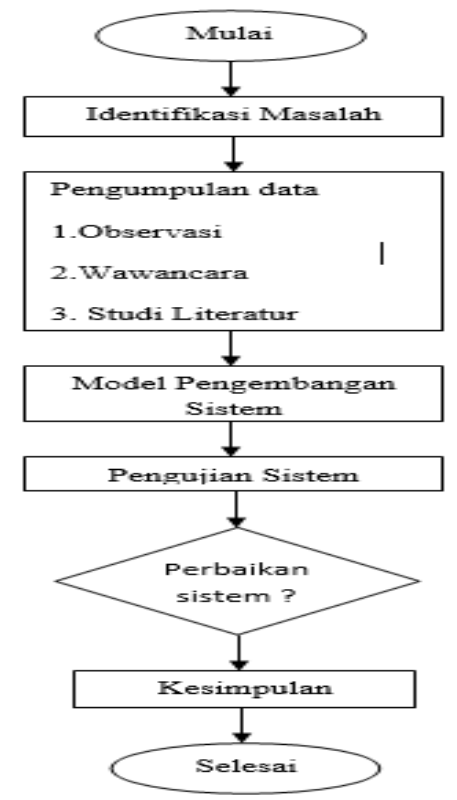

Gambar 1. Model rancangan penelitian 


\subsection{Identifikasi Masalah}

Identifikasi masalah merupakan langkah awal penting dalam proses penelitian. Dari mendeteksi permasalahan yang diamati, hingga bagaimana solusi penyelesaiannya. Permasalahan dalam penelitian ini didapat setelah melakukan wawancara kepada staff pelayanan dan observasi langsung di kantor Desa.

\subsection{Metode Pengumpulan Data}

Pada penelitian ini teknik pengumpulan data dibagi menjadi 3 bagian sebagai berikut:

1. Observasi

Peneliti melakukan observasi langsung untuk mengumpulkan data yang diperlukan dengan mengamati dan memahami proses pelayanan pembuatan surat keterangan di kantor Desa Pesisir.

2. Wawancara

Wawancara juga dilakukan dengan mengajukan beberapa pertanyaan kepada staff pelayanan di kantor Desa Pesisir terkait proses dan fasitas pendukung untuk mendapatkan informasi terkait pelayanan pembuatan surat keterangan baik proses kovesional maupun yang akan dikembangkan.

\section{Studi Literatur}

Studi pustaka dilakukan untuk mengumpulkan data dan sumber-sumber yang terkait dengan topik yang diangkat dalam penelitian. Studi pustaka dapat diperoleh dari berbagai macam sumber seperti: jurnal, buku, ataupun website lainnya yang masih berkaitan dengan topik yang akan diangkat oleh peneliti dan sistem yang dibutuhkan yaitu seperti teoriteori yang berhubungan dengan pembuatan sistem.

\subsection{Model Pengembangan}

Pengembangan perangkat lunak ini menggunakan metode Air terjun (WaterFall).

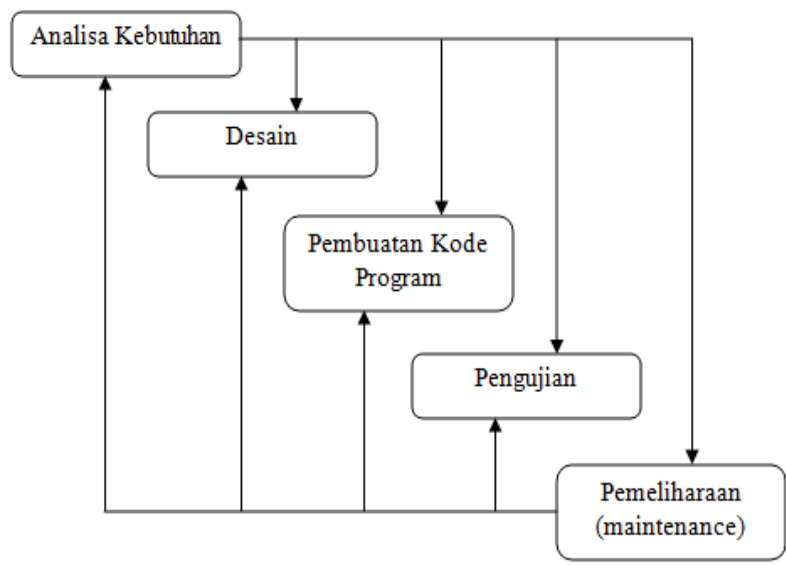

Gambar 2. Model Waterfall
Proses dilakukan secara bertahap, berikut merupakan keterangan alur dari gambar di atas:

1. Analisa Kebutuhan

Analisis sistem dilakukan dengan wawancara, observasi dan studi literatur. Hasil wawancara dan observasi yang diperoleh merupakan data inputan untuk menentukan kebutuhan dalam pengembangan sistem.

2. Desain

Selanjutnya digunakan perancangan sistem dengan menggunakan Alur Diagram (Flowchart) yang merekam persyaratan fungsional sebuah sistem, Flowchart merupakan langkah-langkah penyelesaian masalah yang dituliskan dalam simbol-simbol tertentu (Sitorus, 2015).

Data Flow Diagram (DFD) digunakan untuk menjelaskan alur data dalam sistem yang akan dikembangkan Data Flow Diagram (DFD) merupakan gambaran suatu sistem yang telah ada atau sistem baru yang dikembangkan secara logika tanpa mempertimbangkan lingkungan fisik dimana data tersebut mengalir (Muslihudin \& oktafianto, 2016).

Entity Relationship Diagram (ERD) untuk menjelaskan relasi antar entitas yang ada dalam sistem. ERD (Entity Relationship) adalah suatu model jaringan yang menggunakan susunan data yang disimpan dalam sistem secara abstrak. ERD merupakan model jaringan data yag menekankan pada struktur dan hubungan antardata. (Lubis, 2016)

3. Pembuatan Kode Program

Dalam tahap ini yaitu pengkodingan merupakan menerjemahan dari desain ke bahasa yang bisa dikenal oleh komputer yang dilakukan oleh proggrammer untuk mengerjakan suatu sistem. aplikasi ini dibangun menggunakan Visual Studio Code dengan bahasa pemograman PHP dan Framework Codeigniter serta menyimpan data ke database MySQL dengan menggunakan XAMPP.

4. Pengujian

Setelah sistem baru selesai dibuat maka dilakukan ujicoba terlebih dahulu sebelum diberikan kepada pengguna, apakah sudah sesuai dengan yang diinginkan atau sebaliknya. Jika tidak sesuai dengan apa yang diinginkan pengguna, sistem tersebut direvisi.

a. Pengujian Internal (Blackbox Testing)

Peneliti menggunakan teknik pengujian black box, metode black box ini dapat dilakukan 
hanya sebagai evaluasi tampilan luar (interface) dan fungsionalitasnya. Tanpa mengetahui apa sesungguhnya yang terjadi dalam proses detailnya (hanya mengetahui input dan output). Kelebihan black box adalah untuk mengetahui kesalahan interface nya serta validasi fungsional. (Utami \& Asnawati, 2015)

b. Pengujian eksternal (User)

Selain melakukan pengujian internal perlu adanya pengujian eksternal (pengujian langsung ke user) yang akan menggunakan sistem yang baru seperti berikut ini.

Skala linkert merupakan alat untuk mengukuratau mengumpulkan data dengan cara menjawab item butir-butir pertanyaan. (Herlina, 2019).

Untuk menganalisa data ini menggunakan Angket yaitu menggunakan langkah langkah sebagai berikut:

Pertama, Pemberian jawaban menggunakan indikator variabel.

Tabel 1. Penilaian Dengan Skala Linkert

\begin{tabular}{lll}
\hline No & Kategori & Skor \\
\hline 1. & Sangat Setuju & 5 \\
\hline 2. & Setuju & 4 \\
\hline 3. & Netral & 3 \\
\hline 4. & Tidak Setuju & 2 \\
\hline 5. & Sangat Tidak Setuju & 1
\end{tabular}

Kedua, penentuan skor terhadap masingmasing instrument.

a. Perolehan skor $=\Sigma$ skor responden

b. Sekor hasil pengumpulan data $=\Sigma$ skor semua responder

c. Jumlah skor ideal = skor tertinggi tiap $x$ butir jumlah butir soal $x$ jumlah responder

d. Sehingga diperoleh rumus

$$
p=\left(\frac{\text { skor perolehan }}{\text { skor ideal }}\right) \times 100 \%
$$

Gambar 3. Rumus Perhitungan Angket

Pada tahap ini data angket dari responden dapat mengklasifikasikan bahwa sistem yang telah dibuat itu termasuk kategori mana dan dapat dijadikan acuan untuk kelayakan sistem.
Adapun kategori kelayakan persentase dapat dilihat pada tabel 2 sebagai berikut:

Tabel 2. Keterangan atas kategori dari skor jawaban responden

\begin{tabular}{cl}
\hline $\begin{array}{c}\text { Skor } \\
\text { Presentase }\end{array}$ & Interpretasi \\
\hline $25(\%)$ & Tidak Baik \\
\hline $26-50(\%)$ & Kurang Baik \\
\hline $51-75(\%)$ & Baik \\
\hline $76-100(\%)$ & Sangat Baik \\
\hline
\end{tabular}

\section{Diskusi dan Pembahasan}

Berdasarkan permasalahan di Kantor Desa Pesisir Besuki yang telah dibahas pada awal subbab sebelumnya, penulis mencoba merancang dan membangun aplikasi E-village berbasis web dengan harapan dapat membantu permasalahan yang ada. Perancangan ini dibuat sebagai tahapan untuk mempersiapkan proses implementasi sistem yang diinginkan. Perancangan sistem ini bertujuan untuk memberikan gambaran mengenai sistem yang di usulkan dengan menyempurnakan sistem yang berjalan di Kantor Desa Pesisir Besuki.

\subsection{Hasil Observasi dan Wawancara}

Observasi yang dilakukan di Kantor Desa Pesisir Besuki menghasilkan fakta bahwa dalam proses pengajuan dan pembuatan surat, masyarakat Desa Pesisir membuat surat dengan format yang tidak sesuai dengan kententuan dari kantor desa. Berdasarkan hasil observasi juga didapatkan bahwa tidak tersedianya sistem yang dapat membantu kinerja staff Kantor Desa dalam pelayanan pengajuan surat.

Dari hasil wawancara yang dilakukan dengan Bapak Iqbal Fatoni, S.Kom selaku staff pelayanan di Kantor Desa Pesisir bahwa pelayanan yang ada saat ini tidaklah efektif dikarenakan masyarakat yang ingin melakukan pengajuan surat harus datang, mengantri dan menunggu surat selesai dibuat di kantor desa. Hal ini membutuhkan waktu yang lebih lama karena proses dan pelayanannya kurang efektif dan efisien.

\subsection{Analisis Sistem Lama}

Dari analisa metode penelitian yang telah dilakukan maka dapat dideskripsikan bahwa sistem lama pada proses pelayanan pembuatan surat keterangan adalah masyarakat harus mendatangi langsung kantor desa, mengantri 
dan menunggu surat selesai dibuat. Berdasarkan hasil pengumpulan data yang dilakukan maka kekurangan yang paling utama ialah dalam proses pelayanan pembuatan surat keterangan.

Hasil dari observasi dan wawancara yang dilakukan menghasilkan alur proses bisnis dari pelayanan pengajuan permohonan surat keterangan adalah sebagai berikut:

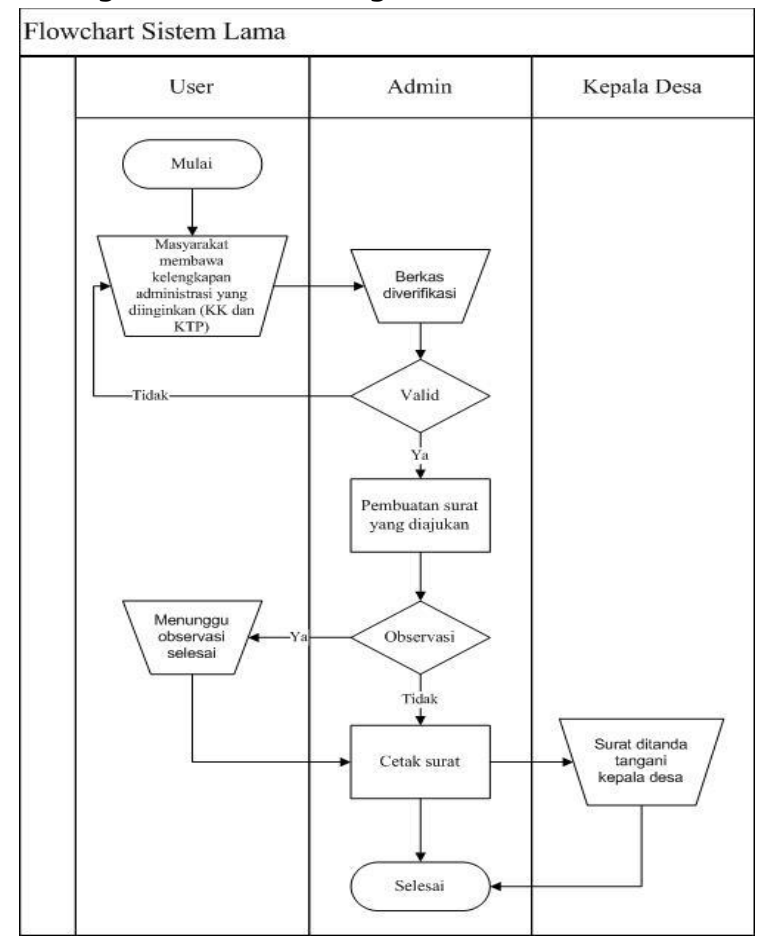

Gambar 4. Flow Chart system pengajuan surat secara konvensional

Penjelasan flowchart sistem lama:

1. Masyarakat datang ke kantor desa dengan membawa kelengkapan administrasi yang diinginkan.

2. Berkas tersebut bisa berupa: KK, KTP, dan lain sebagainya.

3. Selanjutnya berkas di verifikasi (cek) oleh pihak petugas kantor desa, jika belum lengkap maka masyarakat harus melengkapi persyaratan berkas.

4. Jika berkas sudah lengkap maka surat permohonan akan dibuat oleh petugas.

5. Selanjutnya bila dalam pembuatan surat perlu observasi seperti surat tanah maka masyarakat harus menunggu observasi selesai.

6. Lalu surat akan dicetak.

7. Dan ditandatangani Kepala Desa.

Proses ketika ingin melakukan pembuatan surat keterangan masih dilakukan secara konvensional, di mana masyarakat harus datang, mengantri dan menunggu surat selesai dibuat di kantor desa. Ada pula masayarakat yang sudah membuat surat dari rumah dengàn harapan dapat diproses lebih cepat. Inisiatif masyarakat tersebut sangat membantu dalam proses pembuatan surat agar lebih cepat namun tidak jarang pula format surat yang dibuat oleh masyarakat tidak sesuai dengan yang sudah ditentukan dari kantor desa baik dari segi penulisan maupun tata bahasa.

Kemudian dilihat dari Kepatuhan terhadap protokol kesehatan masyarakat yang melakukan pengajuan surat keterangan dapat dikatakan sudah patuh dalam lingkup kantor desa setempat. Namun diuar itu penggunakaan masker masih ada yang tidak sesuai dan kurang memperhatikan jarak.

\subsection{Analisis Kebutuhan System}

1. Kebutuhan Fungsional

Identifikasi kebutuhan fungsional sistem ditetapkan dengan melihat pada kebutuhan pengguna sistem serta hasil dari analisis solusi masalah yang telah dijabarkan sebelumnya. Berikut ini adalah kebutuhan fungsional system yang akan dikembangkan:

a. Kebutuhan Petugas Desa:

1) Mengetahui jumlah permohonan surat

2) Persetujuan pengesahan dilakukan secara manual

3) Mengetahui profil desa yang diunggah pada web

b. Kebutuhan Administrator:

1) Input data profil desa

2) Input data potensi desa (Perekonomian dan Wisata)

3) Verifikasi proses pengajuan surat dari masyarakat (surat beda nama, surat keterangan Usaha, surat keterangan umum)

4) Cetak surat untuk disahkan oleh kepala desa

c. Kebutuhan Masyarakat:

1) Mengetahui format pengajuan surat

2) Mengajukan surat melalui website dari manapun

3) Mengetahui progress pengajuan surat.

2. Kebutuhan Non Fungsional

Kabutuhan non fungsional yang didapat dari hasil observasi dan wawancara adalah sebagai berikut:

a. Tidak menggunakan server sendiri atau menggunakan layanan hosting komersil

b. Aplikasi dapat diakes menggunakan smartphone yang terdapat web browser.

c. Perangkat komputer dan printer untuk admin yang sudah teristal web browser. 


\section{d. Petugas Administrator atau SDM yang mampu mengoperasikan perangkat computer.}

\subsection{Desain Sistem Baru}

Berdasarkan permasalahan yang telah diperoleh dari wawancara, observasi, dan analisis terhadap sistem lama, maka dikembangkanlah desain sistem baru untuk website administrasi di Desa Pesisir Kabupaten Besuki antara lain sebagai berikut:

1. Flowchart

a. Flowchart Administrator

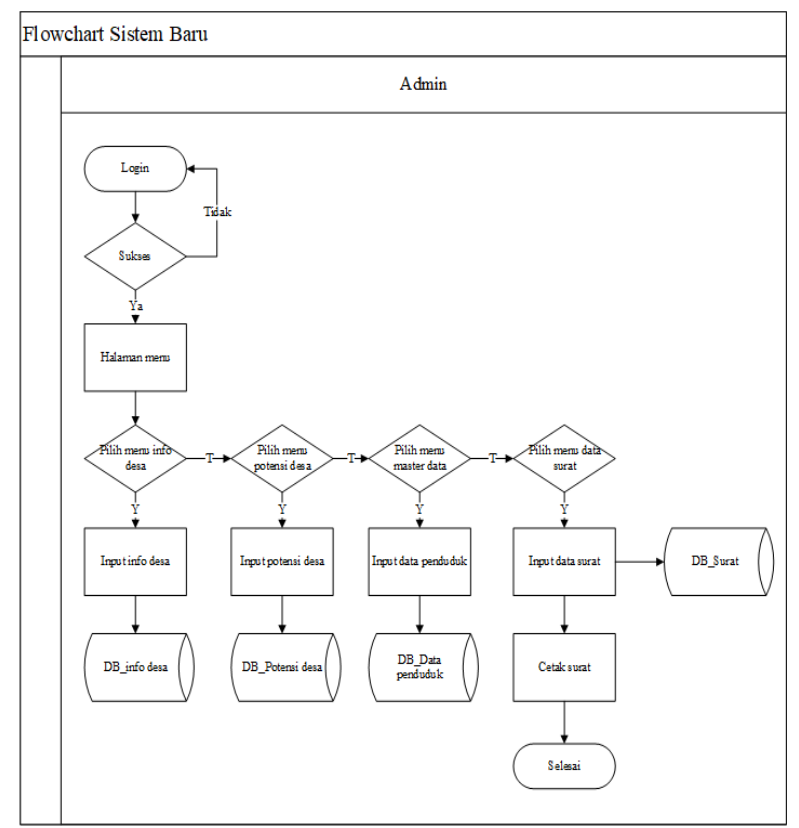

Gambar 5. Flowchart administrator

Penjelasan Gambar 5 sebagai berikut:

1) Admin melakukan login.

2) Jika login sukses, Admin bisa memilih fitur di halaman menu.

3) Jika memilih fitur info desa, admin dapat menginput info desa. Info desa tersebut akan tersimpan di database info desa.

4) Jika memilih fitur Potensi desa, admin dapat menginput potensi desa. potensi desa tersebut akan tersimpan di database potensi desa.

5) Jika memilih fitur master data, admin dapat menginput master data seperti data penduduk, data mutasi dan data petugas. Master data tersebut akan tersimpan di database master data.

6) Jika memilih fitur data surat, admin dapat mencetak surat juga menginput surat. Data surat tersebut akan tersimpan di database data surat.

\section{b. Flowchart Pemohon}

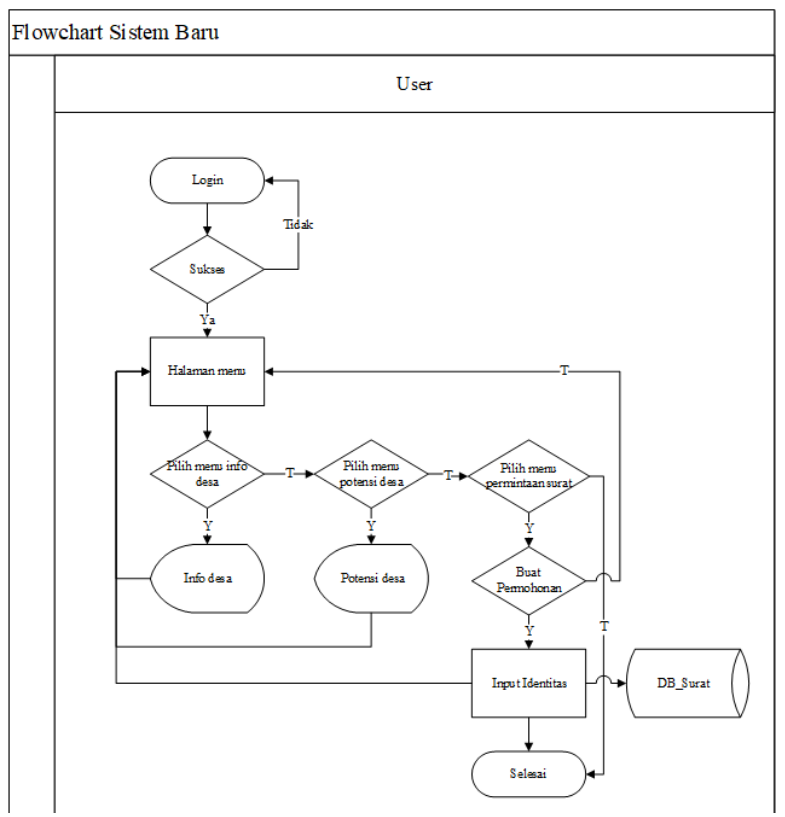

Gambar 6. Flowchart Pemohon

Penjelasan Gambar 6 sebagai berikut:

1) Masyarakat melakukan login.

2) Jika login sukses, masyarakat bisa memilih fitur di halaman menu.

3) Jika memilih fitur info desa, maka akan tampil halaman info desa. Disini masyarakat dapat melihat visi \& misi serta profil desa.

4) Jika memilih fitur potensi desa, maka akan tampil halaman potensi desa. Masyarakat dapat melihat potensi desa seperti potensi ekonomi dan wisata desa.

5) Jika memilih fitur permintaan surat, maka akan tampil beberapa menu surat seperti surat bedanama, keterangan usaha dan keterangan umum. Masyarakat bisa melakukan pengajuan surat dengan menginputkan indentitasnya. Permohonan surat tersebut akan tersimpan ke database dan terkirim ke admin desa.

2. DFD (Data Flow Diagram)

Data Flow Diagram (DFD) merupakan bentuk diagram yang menggambarkan arus data dalam sebuah sistem. Pemberian pada arus data ini penting karena arus data berkaitan dengan Database. Terdapat beberapa level dalam perancangan DFD, yaitu:

a. Diagram Berjenjang

Bagan berjenjang merupakan ringkasan yang memetakan seluruh proses yang berlangsung pada sebuah sistem. Desain bagan berjenjang pada sistem ini adalah sebagai berikut: 


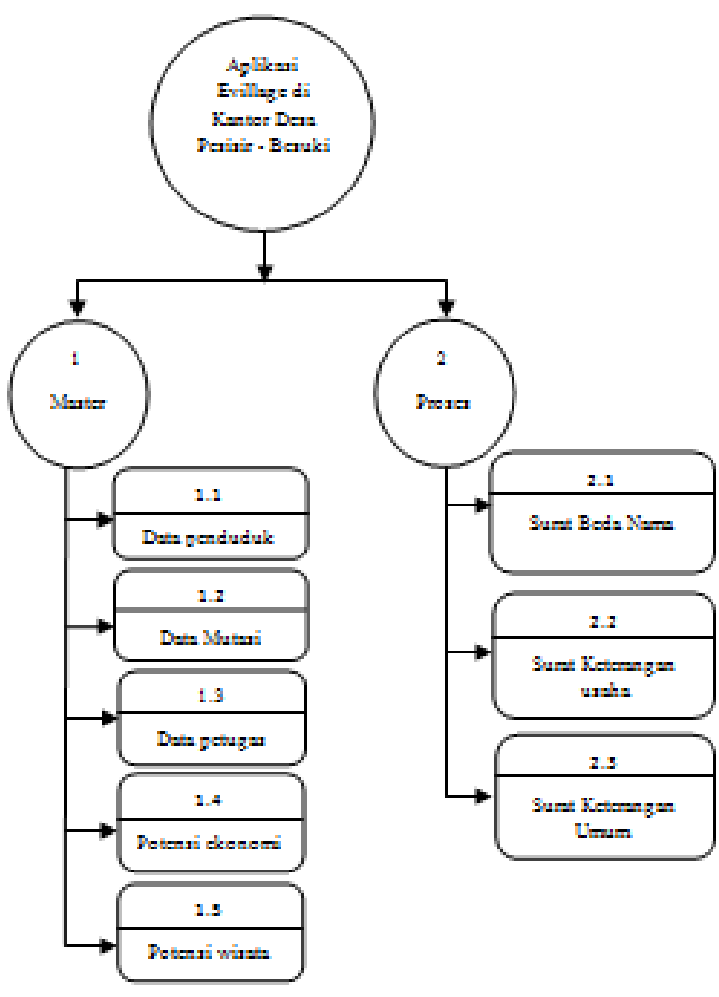

Gambar 7. Diagram Berjenjang

b. Konteks Diagram

Diagram konteks menjelaskan hubungan dari entitas-entitas yang ada dalam sistem. Diagram konteks pada sistem baru dapat dilihat pada di bawah ini :

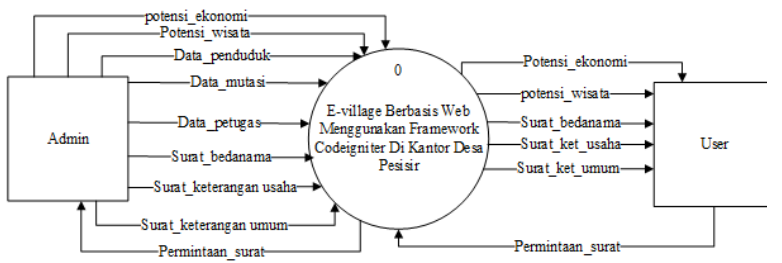

Gambar 8. Konteks Diagram

c. Data Flow Diagram Level 1

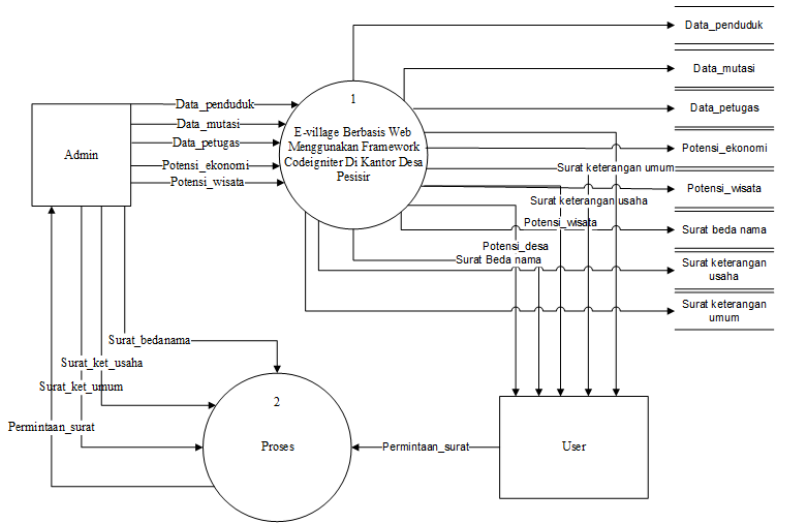

Gambar 9. DFD level 1

\section{ERD (Entity Relationship Diagram)}

Dari proses yang dijelaskan diatas, maka dapat dilihat adanya beberapa entitas yang saling berkaitan dan membentuk suatu kesatuan yang bergerak secara sistemik menuju tujuan. Untuk menjelaskan alur hubungan antara entitas tersebut, kami gambarkan Entity Relationship Diagram(ERD) sebagai berikut:

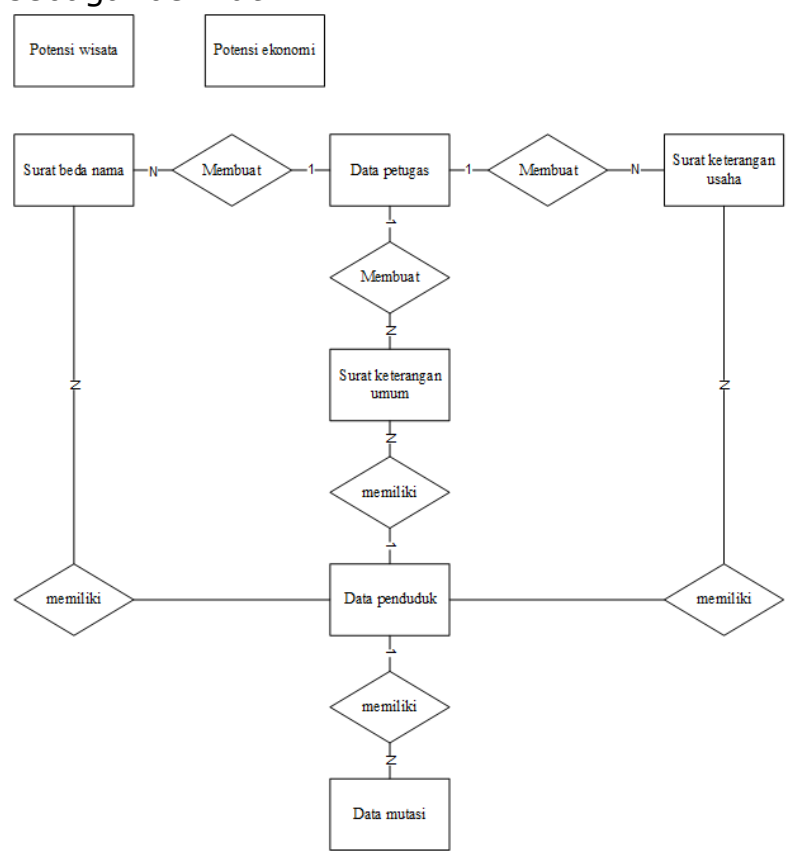

Gambar 10. Entity Relationship Diagram

Kamus Data ERD pada Gambar 10:

1) Datapetugas $=\{$ id_petugas*, username, nama, password, alamat, level, no_telpon, foto\}

2) Data penduduk $=\{$ id_penduduk*, nik, nama_penduduk, alamat, agama, tempat_lahir, tanggal_lahir, jenis_kelamin, golongan_darah \}

3) Data mutasi $=\{$ id_mutasi*, id_penduduk, daerah_asal, daerah_tujuan, alasan, catatan\}

4) Potensi ekonomi $=\{$ id_ ekonomi*, pekerjaan, jumlah_penduduk\}

5) Potensi wisata $=\{$ id_wisata*, dekripsi, lokasi, foto\}

6) Surat bedanama $=\{$ id_surat*, no_ surat, id_penduduk, keterangan1, nama, jenis_kelamin, tanggal_lahir, tempat_lahir, pekerjaan, alamat, keterangan2, tanggal_surat\}

7) Surat keterangan usaha $=\{$ id_surat*, no_surat, id_penduduk, nama_usaha, tanggal, alamat_usaha, no_telpon_kantor, jenis_usaha\}

8) Surat umum $=\{$ id_surat*, no_surat, id_penduduk, keterangan, tanggal\} 


\section{d. Struktur Database}

Dalam database yang akan menampung seluruh jenis data sehingga perlu disusun pola struktur database sesuai dengan jenis data, lebar data dari masing masing field/kolom. Database dibuat dengan menggunakan MySQL yang terdiri dari beberapa tabel seperti pada gambar 10.

\section{Desain Interface}

Desain interface adalah proses yang dimana dalam implementasi analisis sistem ke dalam sebuah perangkat lunak. Hal ini bertujuan agar dalam pemrograman tidak terjadi kesalalan dan berkesinambungan dari hasil analisa yang telah ada

a. Desain Input Output

1) Halaman Login

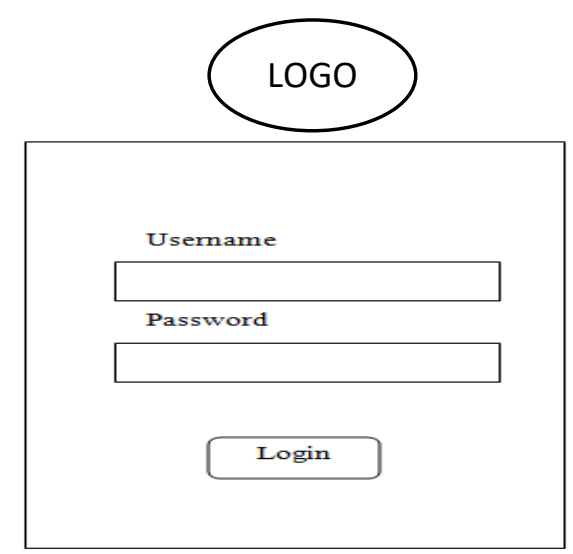

Gambar 11. Halaman Login

2) Halaman Menu Utama

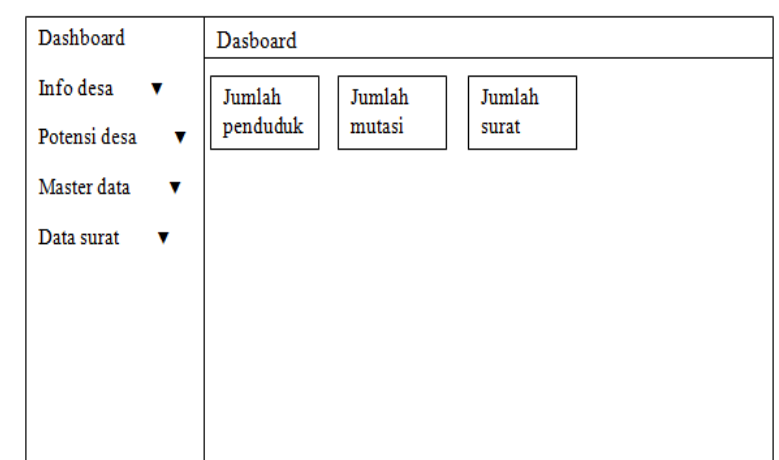

Gambar 12. Halaman Menu Utama (Administrtor)
3) Halaman info desa (Profil Desa)

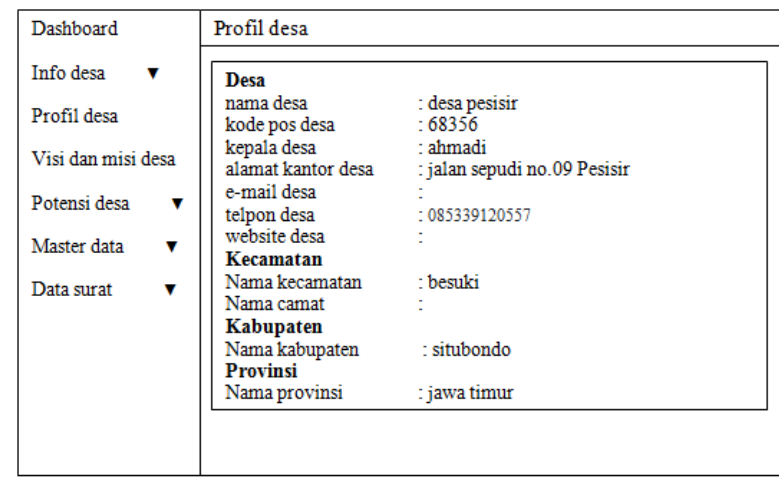

Gambar 13. Halaman profil desa (Administrtor)

4) Halaman info desa (visi dan misi desa).

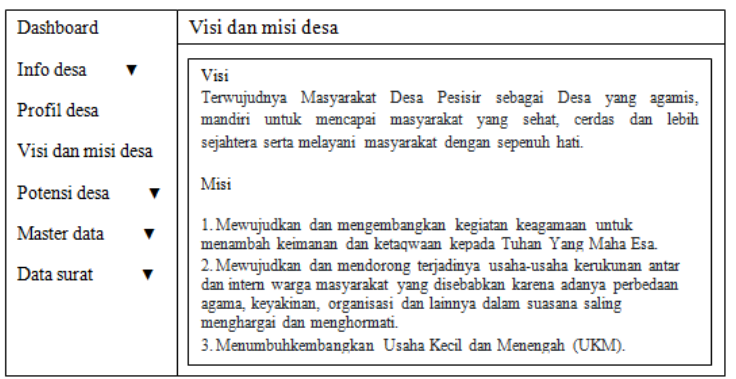

Gambar 14. Halaman profil desa (Administrtor)

5) Desain potensi desa (ekonomi).

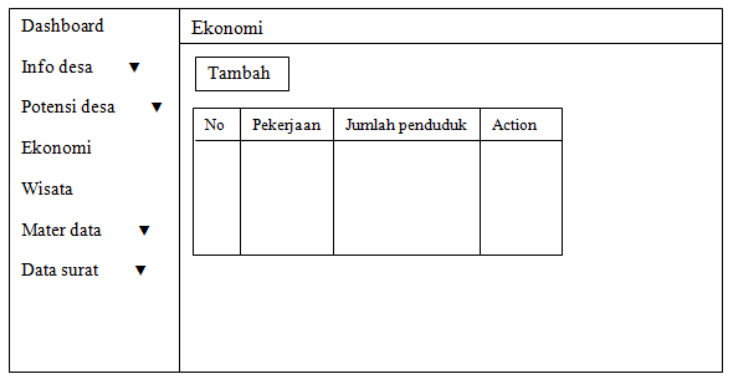

Gambar 15. Desain potensi desa (administrator)

6) Desain potensi desa (wisata)

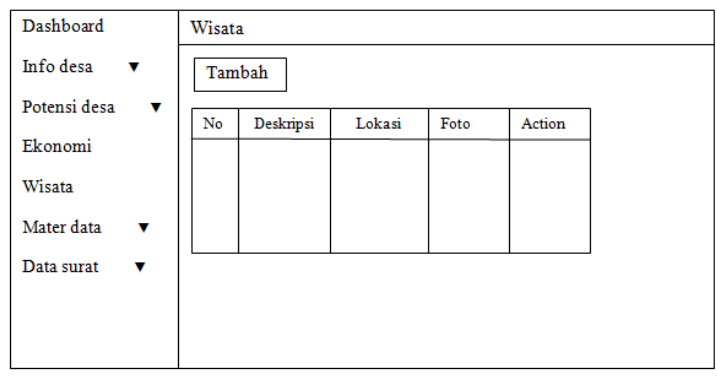

Gambar 16. Halaman kelola data wisata 
7) Halaman Input data penduduk

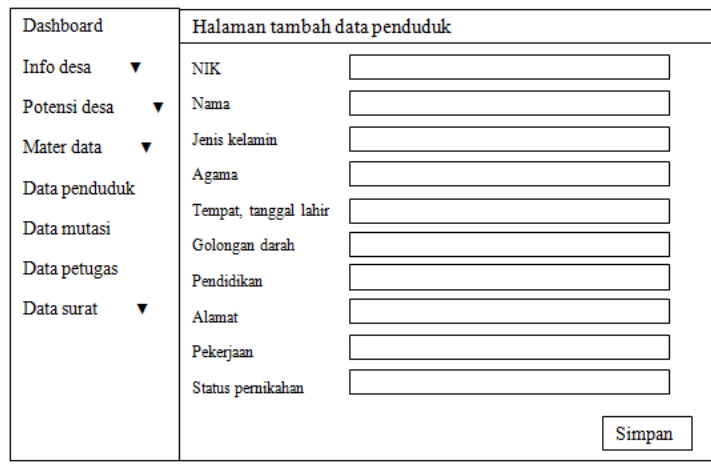

Gambar 17. Halaman kelola data penduduk

8) Halaman Master Data (mutasi)
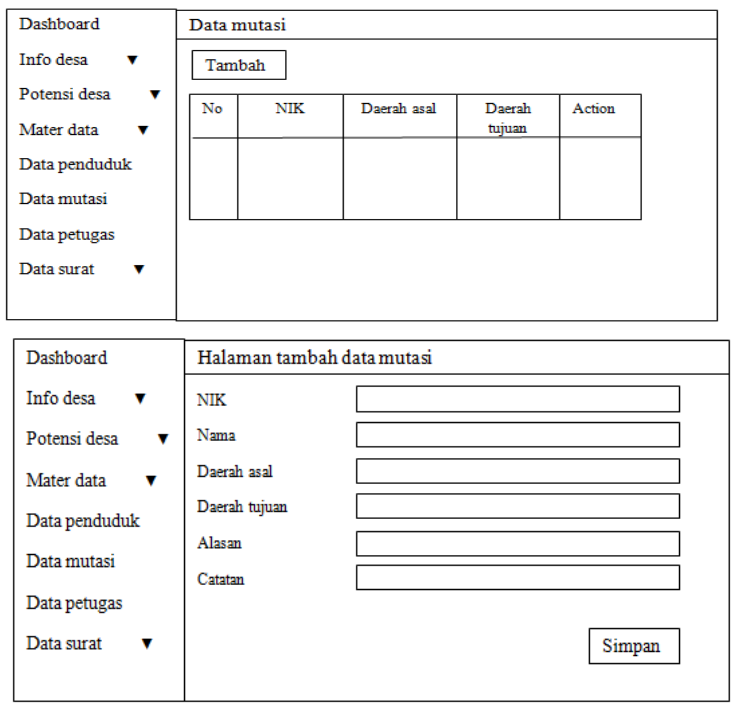

Gambar 18. Halaman kelola data Mutasi

9) Halaman Master Data (mutasi)

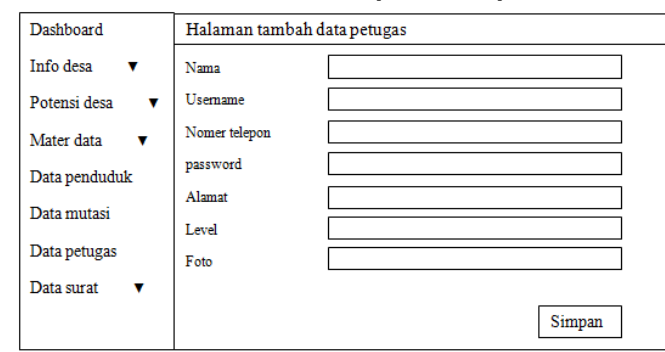

Gambar 19. Halaman kelola data petugas

10) Desain data surat (surat keterangan usaha).

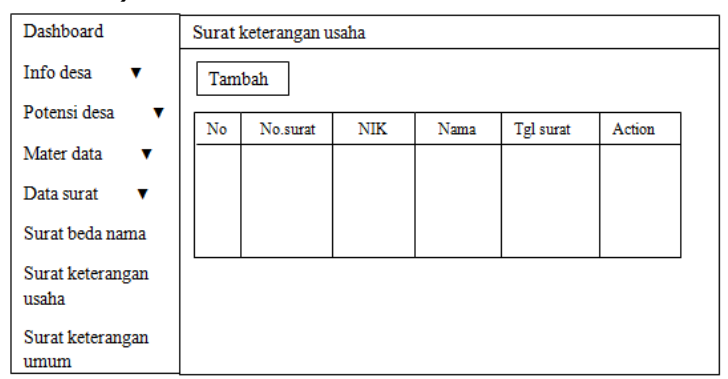

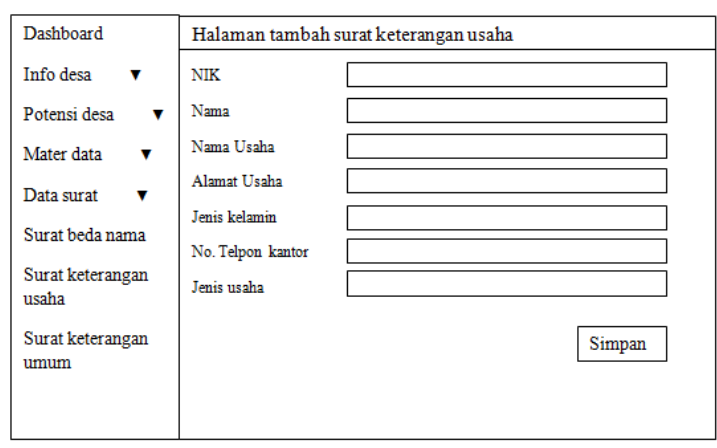

Gambar 20. Halaman kelola data surat keterangan usaha

\subsection{Desain Aplikasi}

Aplikasi ini dibangun menggunakan Visual Studio Code dengan bahasa pemograman PHP dan Framework Codeigniter serta menyimpan data ke database MySQL dengan menggunakan XAMPP. Berikut adalah hasil dari pengembangan aplikasi E-village studi kasus di Desa Pesisir Kab Situbondo.

\section{Halaman Login}

Form login adalah form yang ditampilkan pertama kali dengan tujuan untuk membatasi pengguna yang akan menggunakan aplikasi ini. Admin dan warga yang akan menggunakan aplikasi ini harus login terlebih dahulu Seperti gambar berikut ini:

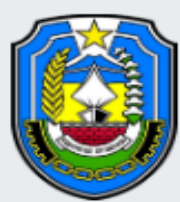

Selamat Datang di Aplikasi

\section{E-VILLAGE}

Desa Pesisir Kabupaten Situbondo

Silahkan Login

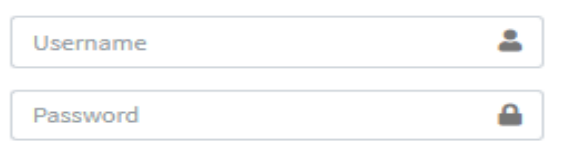

\section{$\rightarrow$ Login}

Gambar 21. Halaman login

2. Halaman Dashboard

Tampilan beranda adalah tampilan yang akan tampil jika login dari admin sukses tapi jika gagal form beranda tidak akan ditampilkan dan akan kembali ke proses login. Form menu utama adalah form yang menampilkan menumenu yang ada dalam aplikasi ini. Seperti gambar berikut ini: 


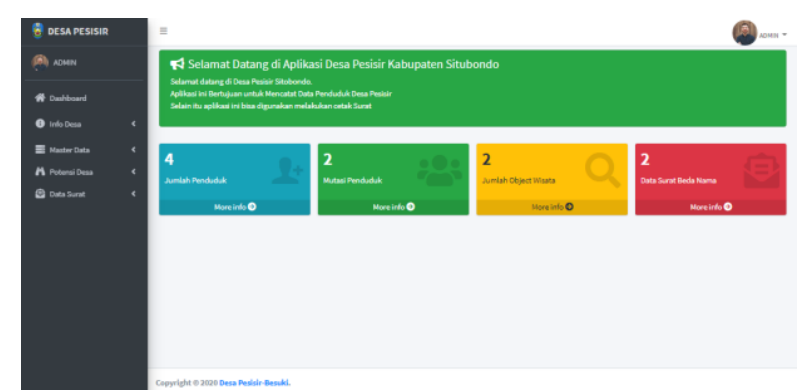

Gambar 22. Dasboard utama

3. Halaman Profil Desa

Tampilan ini adalah tampilan admin dan warga yang menampilkan profil desa.

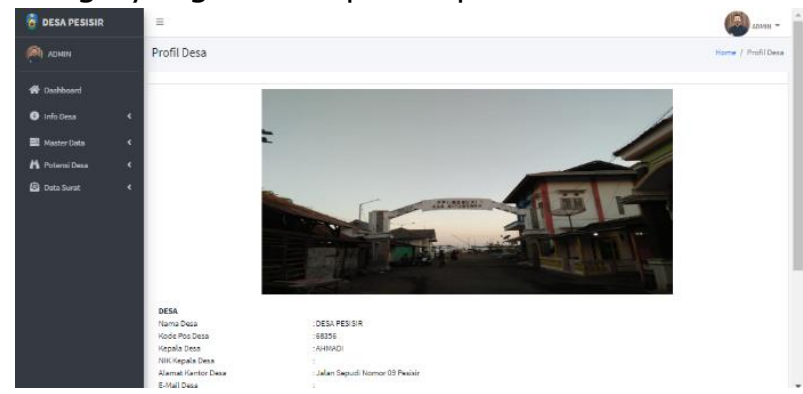

Gambar 23. Halaman profil desa

4. Halaman Visi Misi Desa

Tampilan ini adalah tampilan admin dan warga yang menampilkan visi dan misi desa.

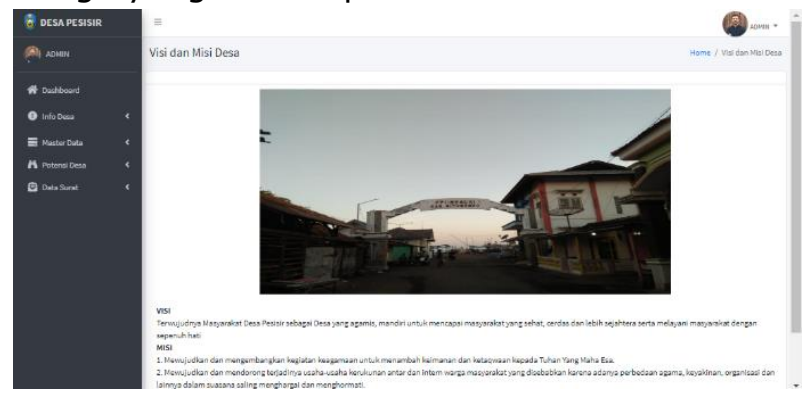

Gambar 24. Halaman visi dan misi desa

\section{Halaman Data Penduduk}

Tampilan ini adalah tampilan halaman admin yang menampilkan semua data penduduk yang sudah tersimpan setelah melakukan input data penduduk, seperti gambar berikut:

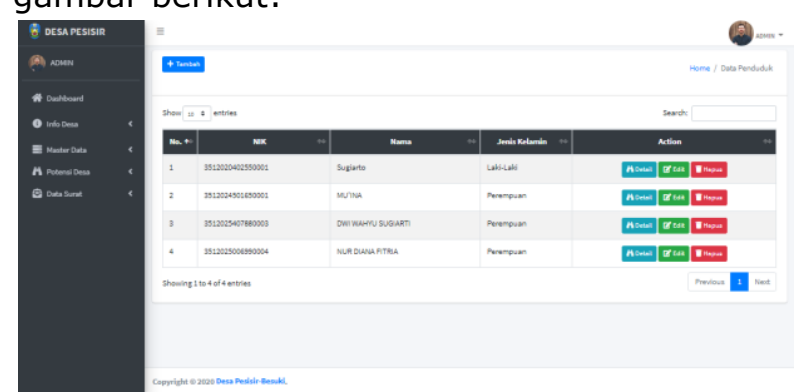

Gambar 25. Halaman kelola data penduduk

6. Halaman Master Data (Tambah Data
Penduduk)
Tampilan ini adalah tampilan halaman admin yang menampilkan input data penduduk, seperti gambar berikut:

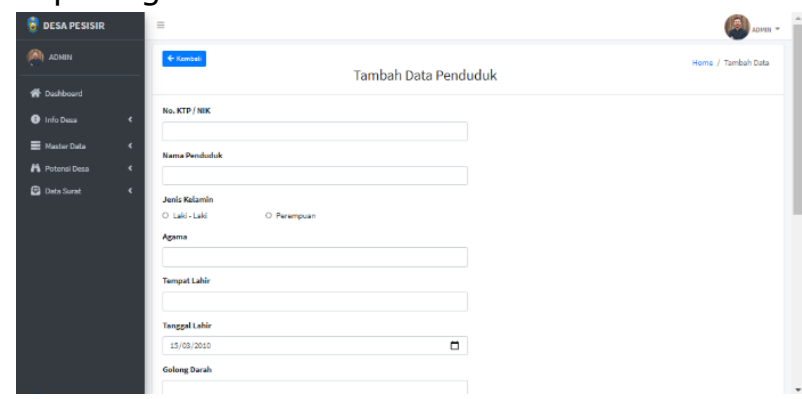

Gambar 26. Halaman master data (tambah data penduduk)

7. Halaman Master Data (Edit Data Penduduk)

Tampilan ini adalah tampilan halaman admin yang menampilkan edit data penduduk yang sudah tersimpan, seperti gambar berikut:

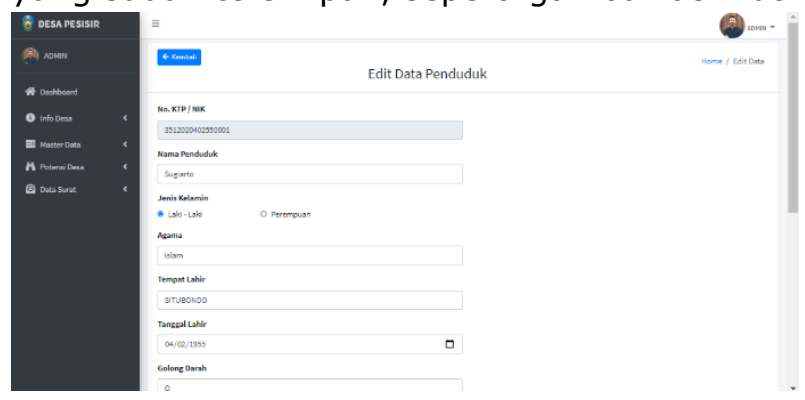

Gambar 27. Halaman master data (edit data penduduk)

8. Halaman Master Data (Detail Data Penduduk)

Tampilan ini adalah tampilan halaman admin yang menampilkan detail data penduduk yang sudah tersimpan, seperti gambar berikut:

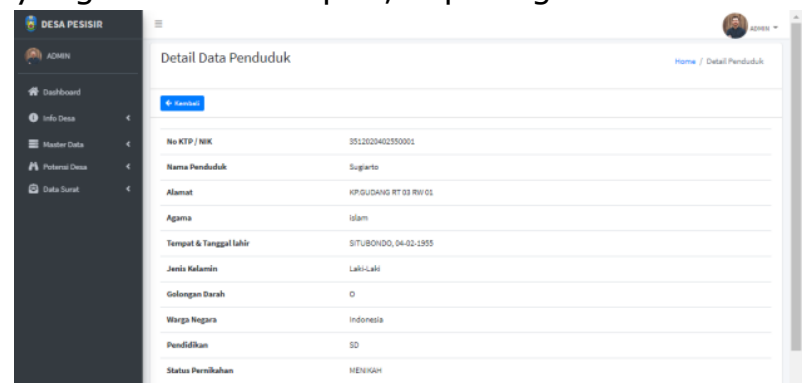

Gambar 28. Halaman master data (detail data penduduk)

9. Halaman Master Data (Data Mutasi)

Tampilan ini adalah tampilan halaman admin yang menampilkan semua data mutasi yang sudah tersimpan setelah melakukan input data mutasi, seperti gambar berikut: 


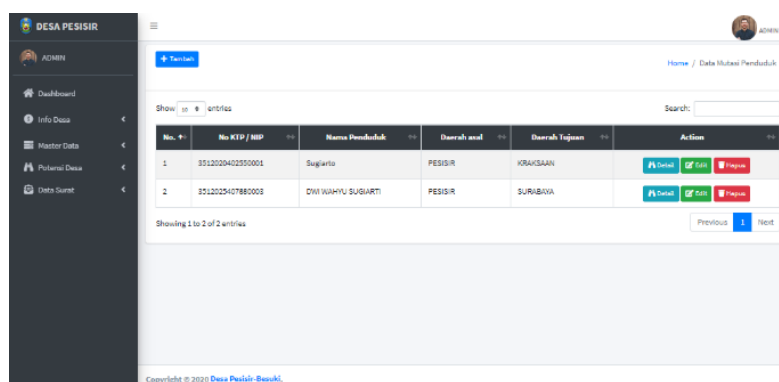

Gambar 29. Halaman master data (data mutasi)

10. Halaman Master Data (Tambah Data Mutasi)

Tampilan ini adalah tampilan halaman admin yang menampilkan input data mutasi, seperti gambar berikut:

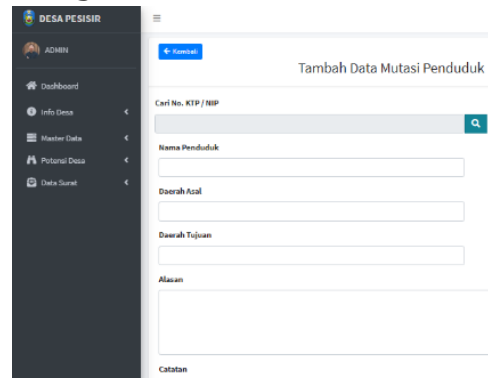

Gambar 30. Halaman master data (tambah data mutasi)

11. Halaman Master Data (Edit Data Mutasi) Tampilan ini adalah tampilan halaman admin yang menampilkan edit data mutasi yang sudah tersimpan, seperti gambar berikut:

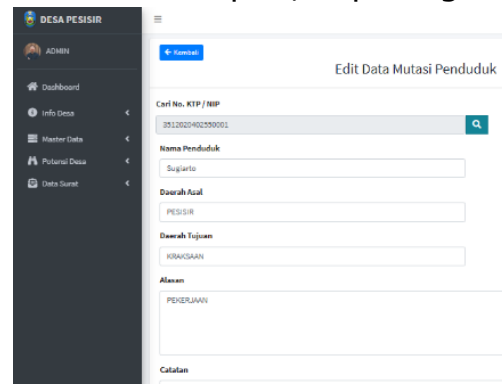

Gambar 31. Halaman master data (edit data mutasi)

12. Halaman Master Data (Data Mutasi) Tampilan ini adalah tampilan halaman admin yang menampilkan semua data mutasi yang sudah tersimpan setelah melakukan input data mutasi, seperti gambar berikut:

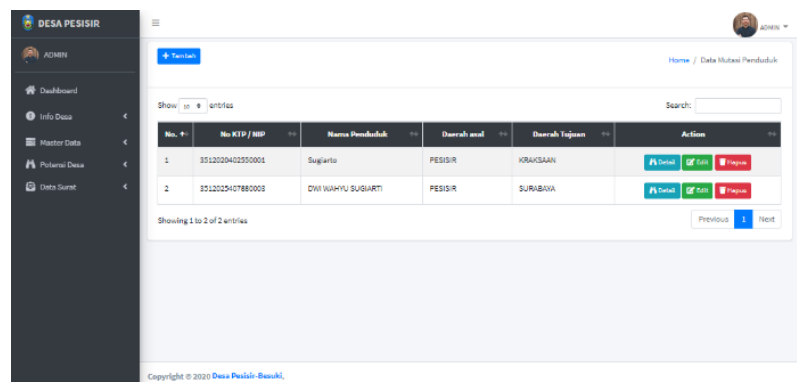

Gambar 32. Halaman master data (data mutasi)

13. Halaman Master Data (Tambah Data Mutasi)

Tampilan ini adalah tampilan halaman admin yang menampilkan input data mutasi, seperti gambar berikut:

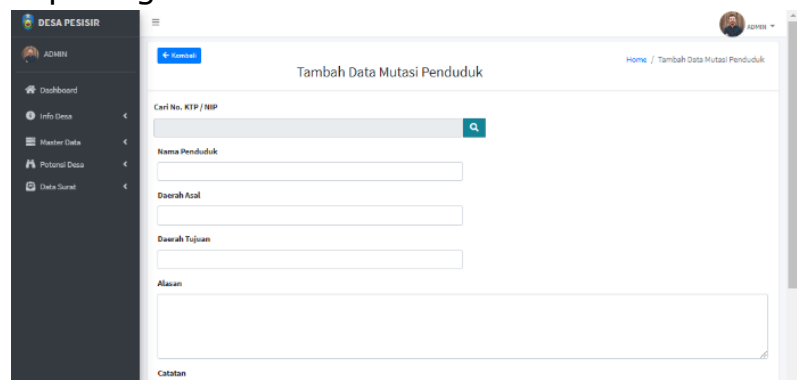

Gambar 33. Halaman master data (tambah data mutasi)

14. Halaman Master Data (Edit Data Mutasi) Tampilan ini adalah tampilan halaman admin yang menampilkan edit data mutasi yang sudah tersimpan, seperti gambar berikut:

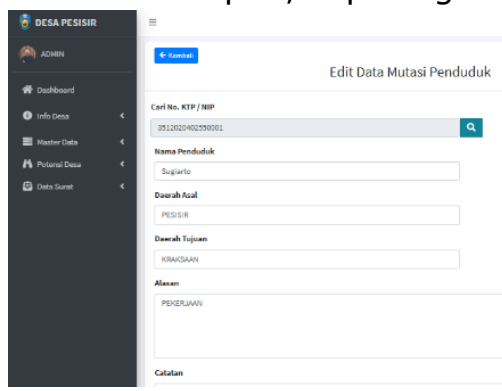

Gambar 34. Halaman master data (edit data mutasi)

\section{Halaman Master Data (Detail Data Mutasi) \\ Tampilan ini adalah tampilan halaman admin yang menampilkan detail data mutasi yang sudah tersimpan, seperti gambar berikut:}




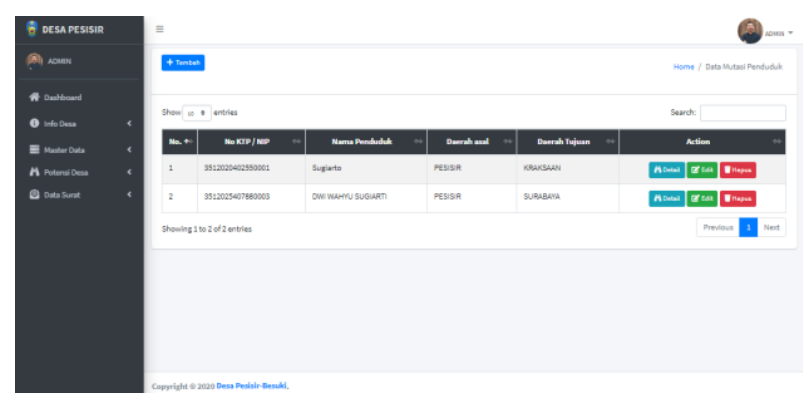

Gambar 35. Halaman master data (detail data mutasi)

16. Halaman Master Data (Data Petugas)

Tampilan ini adalah tampilan halaman admin yang menampilkan semua data petugas yang sudah tersimpan setelah melakukan input data petugas, seperti gambar berikut:

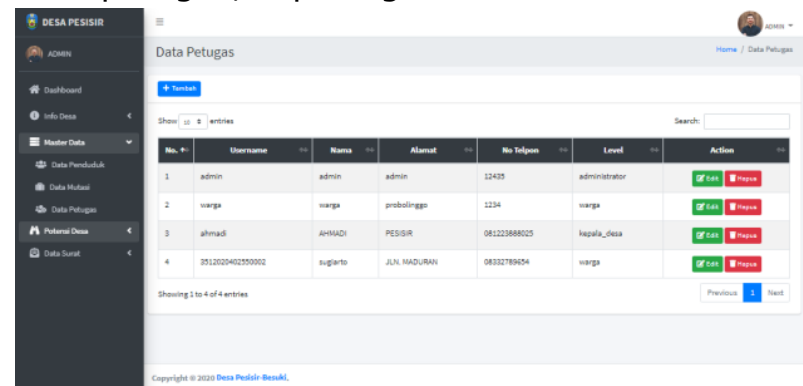

Gambar 36. Halaman master data (data petugas)

17. Halaman Master Data (Tambah Data Petugas)

Tampilan ini adalah tampilan halaman admin yang menampilkan input data petugas, seperti gambar berikut :

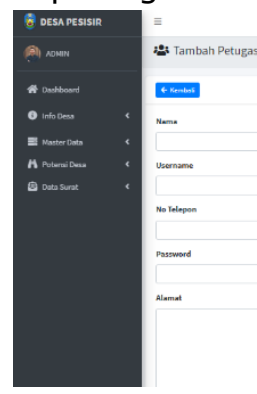

Gambar 37. Halaman master data (tambah data petugas)

18. Halaman Master Data (Edit Data Petugas) Tampilan ini adalah tampilan halaman admin yang menampilkan edit data petugas yang sudah tersimpan, seperti gambar berikut:

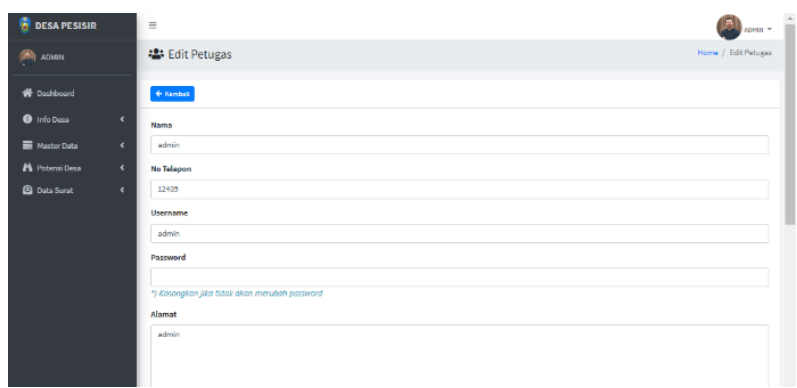

Gambar 38. Halaman master data (edit data petugas)

19. Halaman Potensi Desa (Ekonomi)

Tampilan ini adalah tampilan halaman admin yang menampilkan semua data potensi desa yang sudah tersimpan setelah melakukan input data potensi desa, seperti gambar berikut:

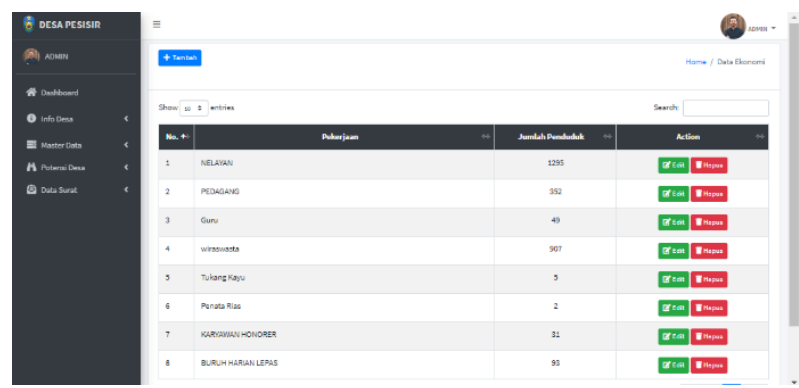

Gambar 39. Halaman potensi desa (ekonomi)

20. Halaman Potensi Desa (Tambah Ekonomi) Tampilan ini adalah tampilan halaman admin yang menampilkan input data potensi desa, seperti gambar berikut:

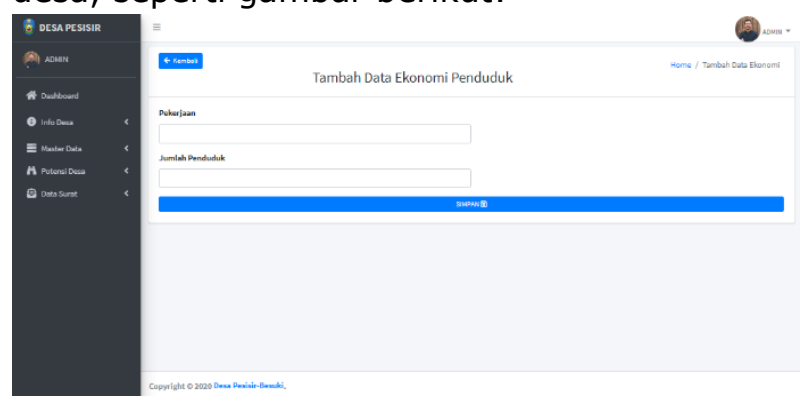

Gambar 40. Halaman potensi desa (tambah ekonomi)

\section{Halaman Potensi Desa (Edit Ekonomi)}

Tampilan ini adalah tampilan halaman admin yang menampilkan edit data potensi desa yang sudah tersimpan, seperti gambar berikut: 


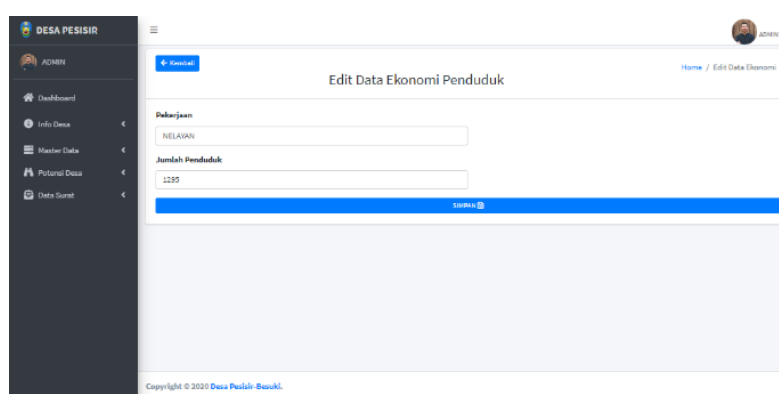

Gambar 41. Halaman potensi desa (edit ekonomi)

\section{Halaman Potensi Desa (Wisata)}

Tampilan ini adalah tampilan halaman admin yang menampilkan semua data potensi desa yang sudah tersimpan setelah melakukan input data potensi desa, seperti gambar berikut:

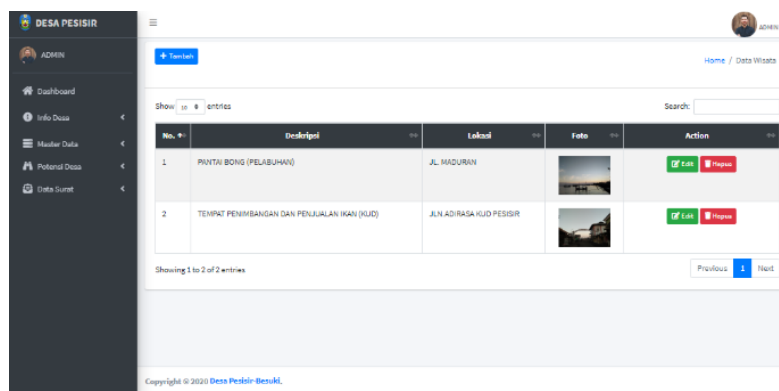

Gambar 42. Halaman potensi desa (wisata)

23. Halaman Potensi Desa (Tambah Wisata) Tampilan ini adalah tampilan halaman admin yang menampilkan input data potensi desa, seperti gambar berikut:

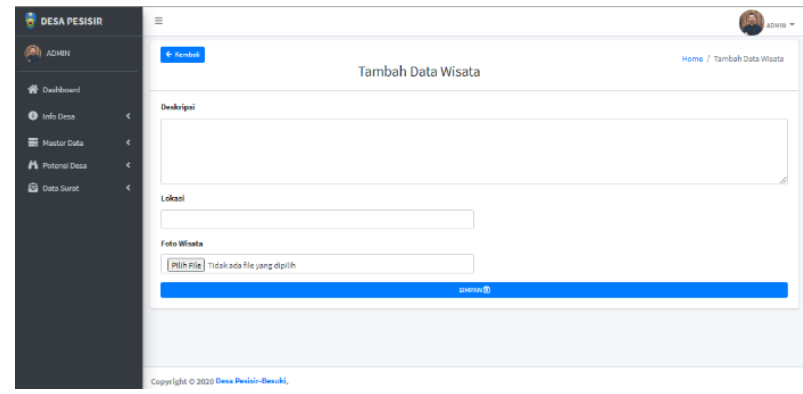

Gambar 43. Halaman potensi desa (tambah wisata)

24. Halaman Potensi Desa (Edit Wisata) Tampilan ini adalah tampilan halaman admin yang menampilkan edit data potensi desa yang sudah tersimpan setelah melakukan input data potensi desa, seperti gambar berikut:

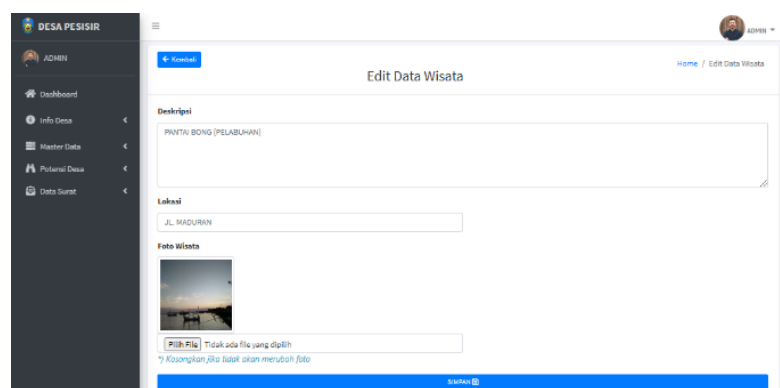

Gambar 44. Halaman potensi desa (edit wisata)

25. Halaman Data Surat (Surat Beda Nama) Tampilan ini adalah tampilan halaman admin yang menampilkan semua data surat (surat beda nama) yang sudah tersimpan setelah melakukan input data surat (surat beda nama), seperti gambar berikut:

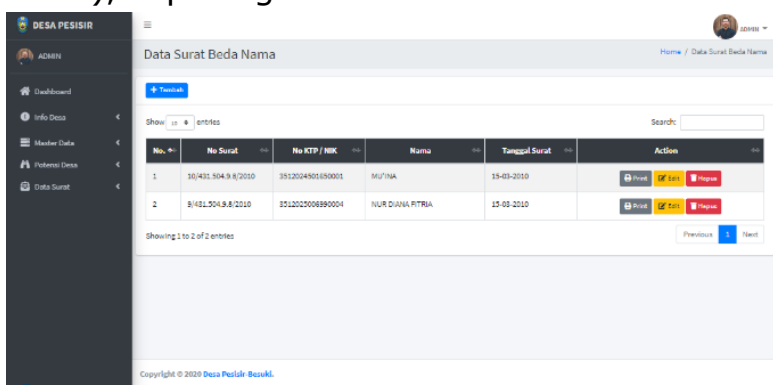

Gambar 45. Halaman data surat (surat beda nama)

26. Halaman Data Surat (Tambah Surat Beda Nama)

Tampilan ini adalah tampilan halaman admin yang menampilkan input data surat (surat beda nama), seperti gambar berikut:

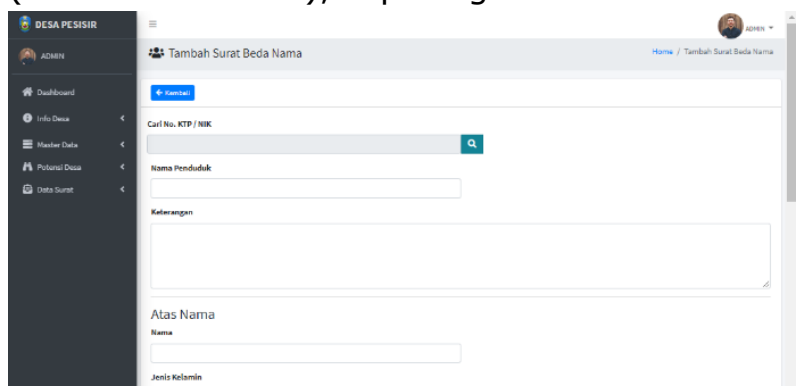

Gambar 46. Halaman data surat (tambah surat beda nama)

27. Halaman Data Surat (Edit Surat Beda Nama)

Tampilan ini adalah tampilan halaman admin yang menampilkan semua data surat (surat beda nama) yang sudah tersimpan setelah melakukan input data surat (surat beda nama), seperti gambar berikut: 


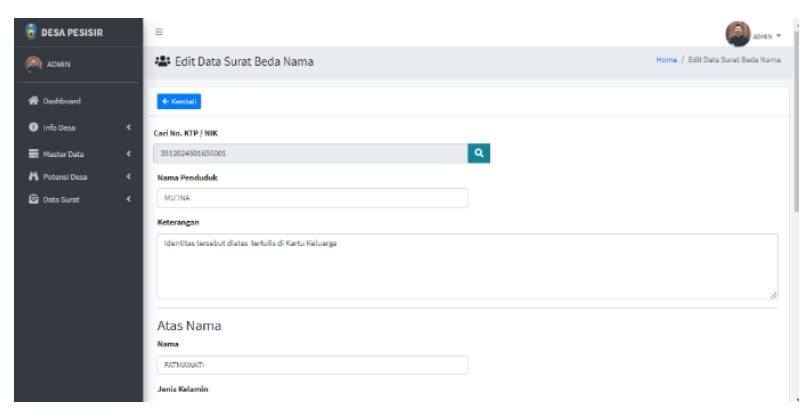

Gambar 47. Halaman data surat (edit surat beda nama)

28. Halaman Data Surat (Print Surat Beda Nama)

Tampilan ini adalah tampilan halaman admin yang menampilkan print data surat (surat beda nama) yang sudah tersimpan setelah melakukan input data surat (surat beda nama), seperti gambar berikut:
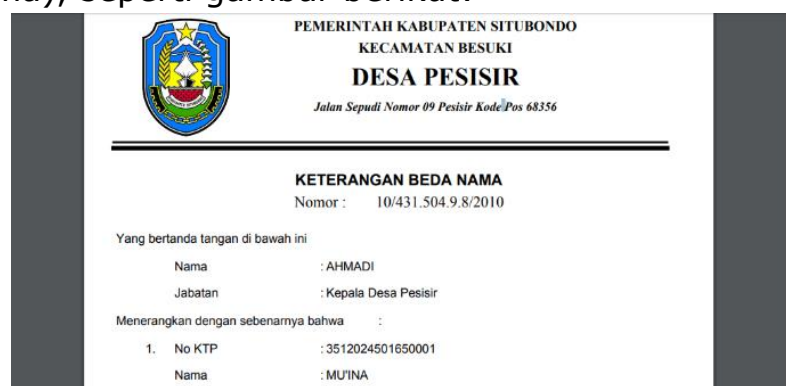

Gambar 48. Halaman data surat (print surat beda nama)

29. Halaman Data Surat (Surat Keterangan Usaha)

Tampilan ini adalah tampilan halaman admin yang menampilkan semua data surat (surat keterangan usaha) yang sudah tersimpan setelah melakukan input surat (surat keterangan usaha), seperti gambar berikut:
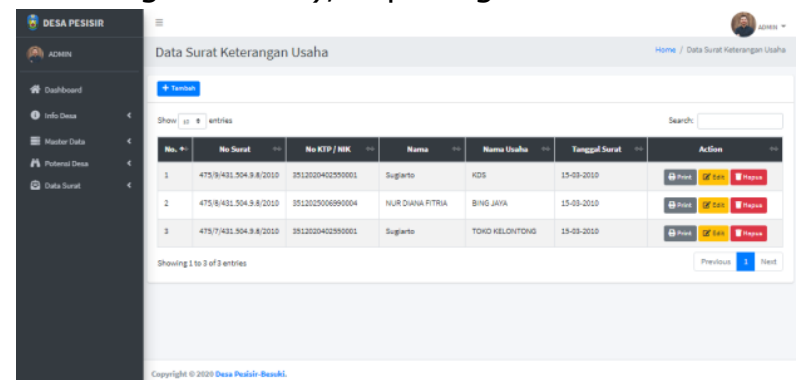

Gambar 49. Halaman data surat (surat keterangan usaha)

30. Halaman Data Surat (Tambah Surat Keterangan Usaha)

Tampilan ini adalah tampilan halaman admin yang menampilkan input data surat (surat keterangan usaha), seperti gambar berikut:

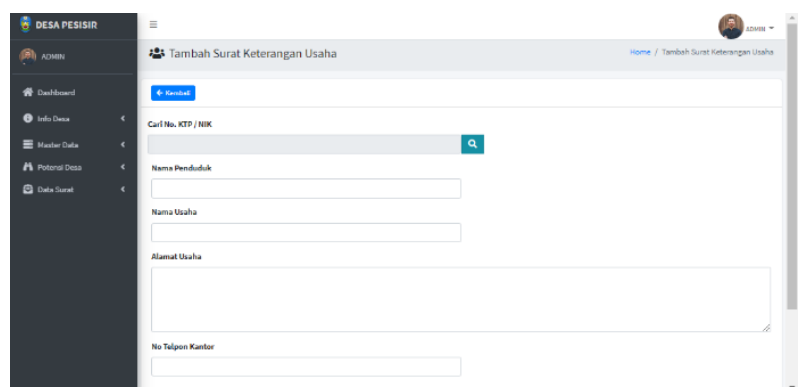

Gambar 50. Halaman data surat (tambah surat keterangan usaha)

31. Halaman Data Surat (Edit Surat Keterangan Usaha)

Tampilan ini adalah tampilan halaman admin yang menampilkan edit data surat (surat keterangan usaha) yang sudah tersimpan setelah melakukan input surat (surat keterangan usaha), seperti gambar berikut:

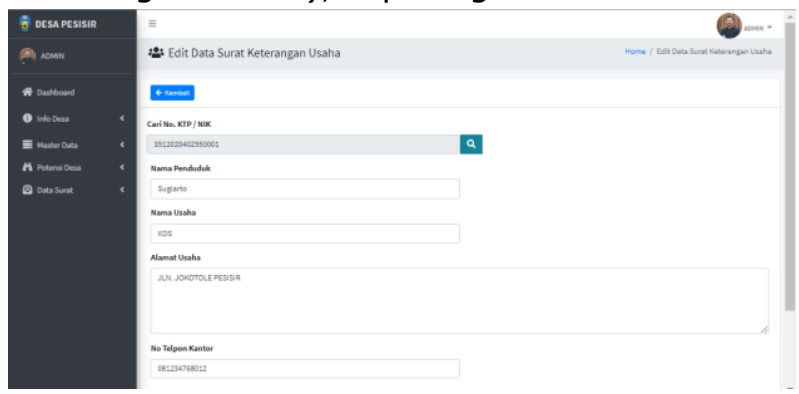

Gambar 55. Halaman data surat (edit surat keterangan usaha)

32. Halaman Data Surat (Print Surat Keterangan Usaha)

Tampilan ini adalah tampilan halaman admin yang menampilkan print data surat (surat keterangan usaha) yang sudah tersimpan setelah melakukan input surat (surat keterangan usaha), seperti gambar berikut:
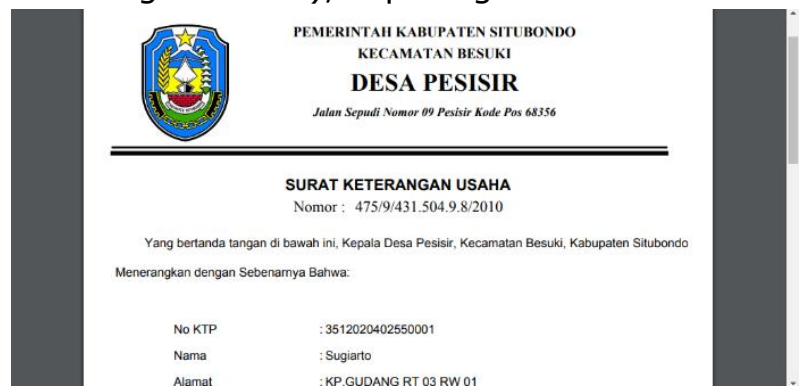

Gambar 56. Halaman data surat (print surat keterangan usaha)

33. Halaman Data Surat (Surat Keterangan Umum)

Tampilan ini adalah tampilan halaman admin yang menampilkan semua data surat (surat keterangan umum) yang sudah tersimpan setelah melakukan input surat (surat keterangan umum), seperti gambar berikut: 


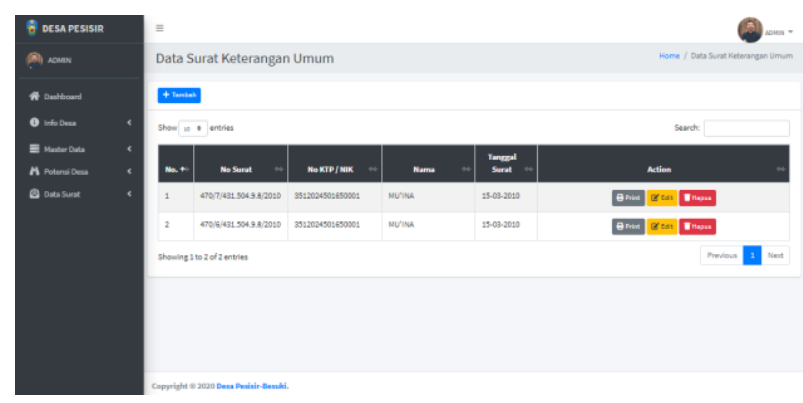

Gambar 1 Halaman data surat (surat keterangan umum)

34. Halaman Data Surat (Tambah Surat Keterangan Umum)

Tampilan ini adalah tampilan halaman admin yang menampilkan input data surat (surat keterangan umum), seperti gambar berikut:

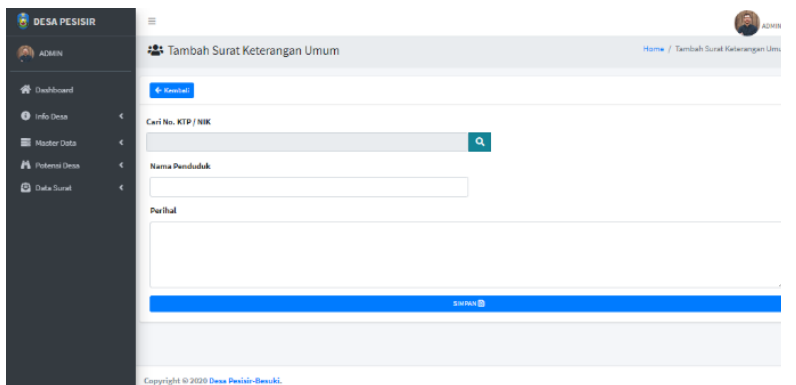

Gambar 2 Halaman data surat (tambah surat keterangan umum)

35. Halaman Data Surat (Edit Surat Keterangan Umum)

Tampilan ini adalah tampilan halaman admin yang menampilkan edit data surat (surat keterangan umum) yang sudah tersimpan setelah melakukan input surat (surat keterangan umum), seperti gambar berikut:

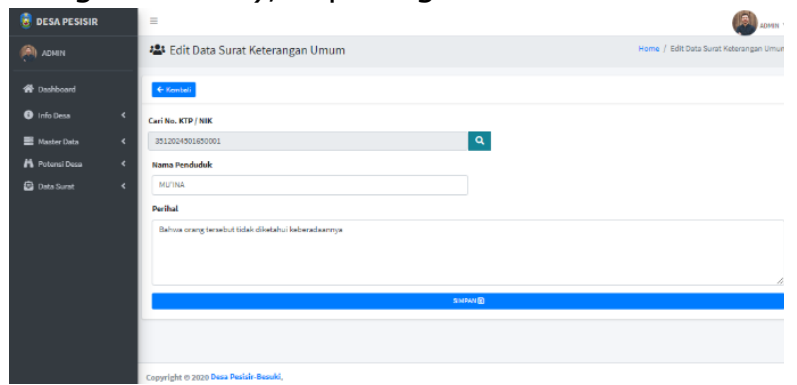

Gambar 3 Halaman data surat (edit surat keterangan umum)

36. Halaman Data Surat (Print Surat Keterangan Umum)

Tampilan ini adalah tampilan halaman admin yang menampilkan print data surat (surat keterangan umum) yang sudah tersimpan setelah melakukan input surat (surat keterangan umum), seperti gambar berikut:

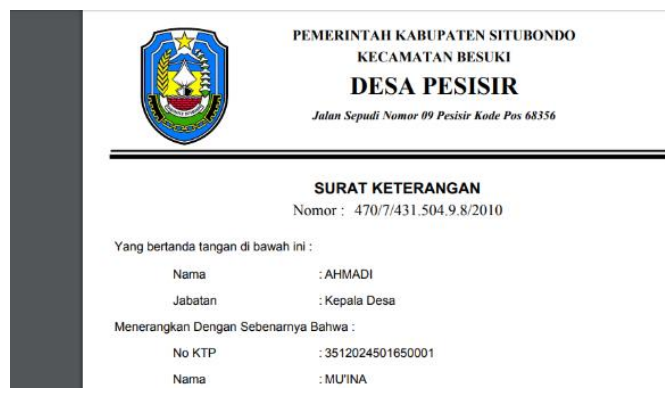

Gambar 4 Halaman data surat (print surat keterangan umum)

\subsection{Tampilan Halaman User}

1. Halaman Dashboard

Tampilan beranda adalah tampilan yang akan tampil jika login dari warga sukses tapi jika gagal form beranda tidak akan ditampilkan dan akan kembali ke proses login. Form menu utama adalah form yang menampilkan menumenu yang ada dalam aplikasi ini. Seperti gambar berikut ini:

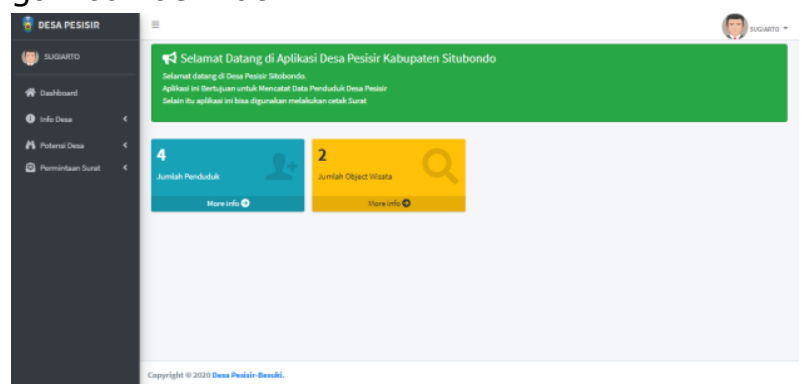

Gambar 5 Halaman dashboard

2. Halaman info desa (profil desa)

Tampilan ini adalah tampilan halaman warga yang menampilkan profil desa. Seperti gambar berikut ini:
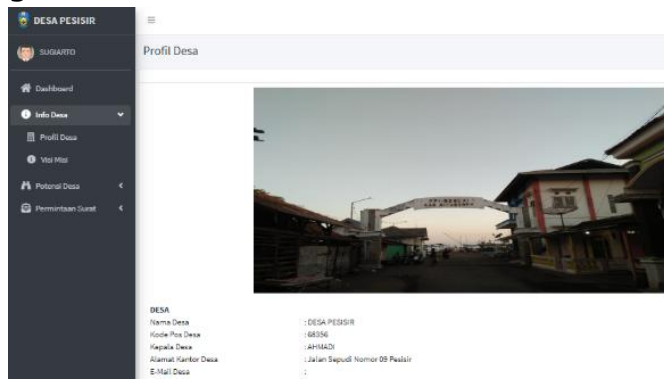

Gambar 6 Halaman info desa (profil desa)

3. Halaman Info Desa (Visi dan Misi Desa)

Tampilan ini adalah tampilan halaman warga yang menampilkan visi dan misi desa. Seperti gambar berikut ini: 


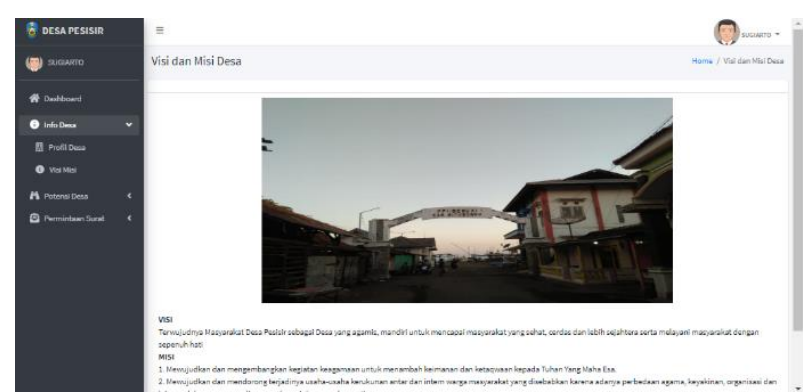

Gambar 7 Halaman info desa (visi dan misi desa)

4. Halaman Potensi Desa (Ekonomi Desa)

Tampilan ini adalah tampilan halaman warga yang menampilkan data potensi desa yang sudah diinput oleh admin. Seperti gambar berikut ini:

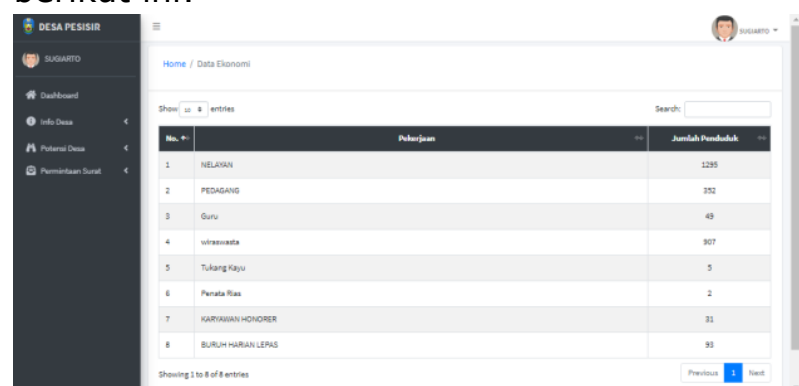

Gambar 8 Halaman potensi desa (ekonomi desa)

5. Halaman Potensi Desa (Wisata Desa)

Tampilan ini adalah tampilan halaman warga yang menampilkan data potensi desa yang sudah diinput oleh admin. Seperti gambar berikut ini:

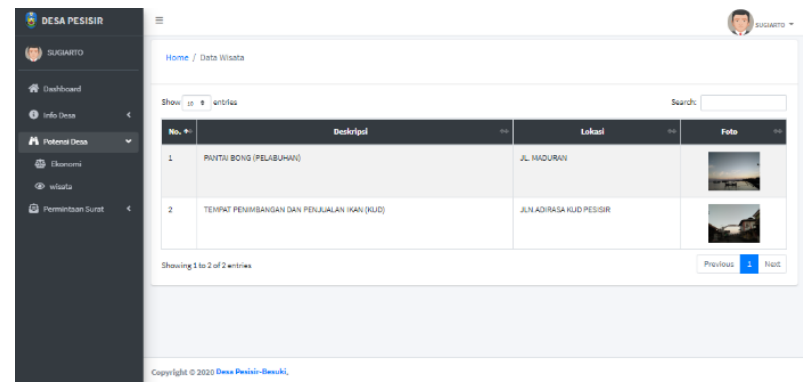

Gambar 4. 9 Halaman potensi desa (wisata desa)

6. Halaman Permintaan Surat (Surat Beda Nama)

Tampilan ini adalah tampilan halaman warga yang menampilkan input permintaan surat (surat beda nama). Seperti gambar berikut ini:

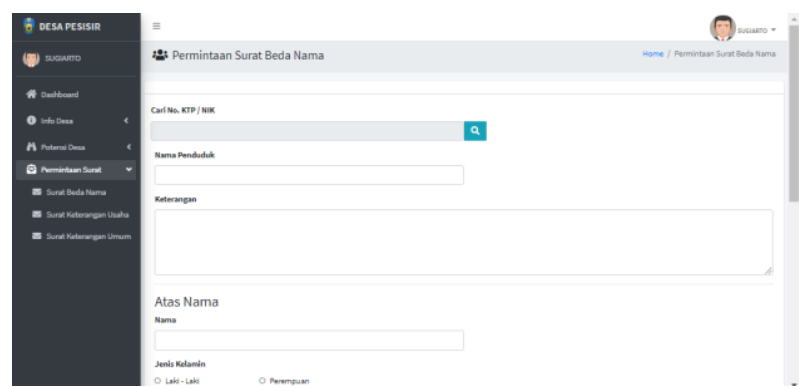

Gambar 4. 10 Halaman permintaan surat (surat beda nama)

7. Halaman Permintaan Surat (Surat Keterangan Usaha)

Tampilan ini adalah tampilan halaman warga yang menampilkan input permintaan surat (surat keterangan usaha). Seperti gambar berikut ini:

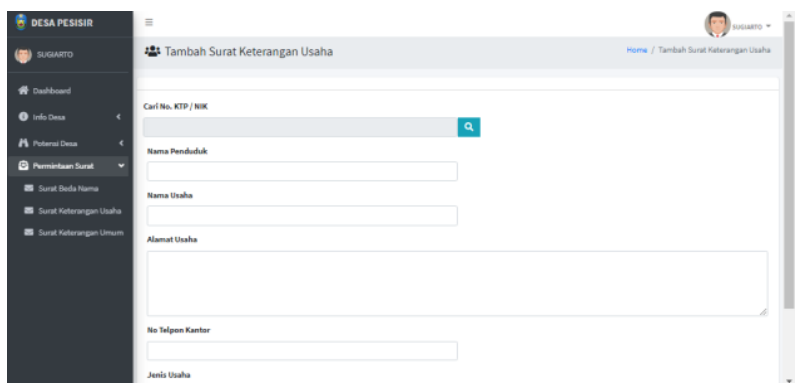

Gambar 4. 11 Halaman permintaan surat (surat keterangan usaha)

8. Halaman Permintaan Surat (Surat Keterangan Umum)

Tampilan ini adalah tampilan halaman warga yang menampilkan input permintaan surat (surat beda nama). Seperti gambar berikut ini:

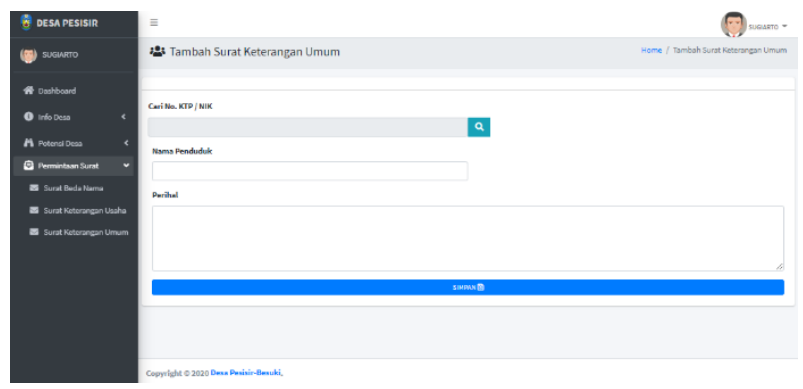

Gambar 4. 12 Halaman permintaan surat (surat keterangan umum)

\subsection{Pengujian}

1. Pengujian Internal

Pengujian pada aplikasi ini hanya memperhatikan aspek fungsional dari aplikasi yang dibuat. Pengujian dilakukan ke beberapa kali hingga tidak ditemuai suatu kesalahan. 
Tabel 4. 1 Pengujian Internal

\begin{tabular}{|c|c|c|c|c|c|}
\hline \multirow[t]{2}{*}{ No } & \multirow{2}{*}{$\begin{array}{l}\text { From yang } \\
\text { Diuji }\end{array}$} & \multirow[t]{2}{*}{ Event } & \multirow{2}{*}{$\begin{array}{l}\text { Hasil Yang } \\
\text { Diharapkan }\end{array}$} & \multicolumn{2}{|c|}{ Hasil } \\
\hline & & & & $\mathrm{Ya}$ & Tidak \\
\hline 1 & Form Login & $\begin{array}{l}\text { menampil } \\
\text { kan form } \\
\text { login. }\end{array}$ & $\begin{array}{l}\text { Menampilkan } \\
\text { Halaman } \\
\text { Utama }\end{array}$ & V & \\
\hline \multirow[t]{4}{*}{2} & $\begin{array}{l}\text { Halaman } \\
\text { Menu }\end{array}$ & $\begin{array}{l}\text { Halaman } \\
\text { info desa }\end{array}$ & $\begin{array}{l}\text { Menampilkan } \\
\text { visi \& misi, } \\
\text { serta profil } \\
\text { desa. }\end{array}$ & V & \\
\hline & & $\begin{array}{l}\text { Halaman } \\
\text { master } \\
\text { data }\end{array}$ & $\begin{array}{l}\text { Menampilkan } \\
\text { data } \\
\text { penduduk, } \\
\text { data mutasi, } \\
\text { data petugas }\end{array}$ & v & \\
\hline & & $\begin{array}{l}\text { Halaman } \\
\text { potensi } \\
\text { desa }\end{array}$ & $\begin{array}{l}\text { Menampilkan } \\
\text { potensi } \\
\text { ekonomi dan } \\
\text { wisata desa. }\end{array}$ & v & \\
\hline & & $\begin{array}{l}\text { Halaman } \\
\text { data surat }\end{array}$ & $\begin{array}{l}\text { Menampilkan } \\
\text { beberapa } \\
\text { administrasi } \\
\text { surat seperti: } \\
\text { surat } \\
\text { keterangan } \\
\text { umum, surat } \\
\text { keterangan } \\
\text { usaha, dan } \\
\text { surat } \\
\text { bedanama }\end{array}$ & v & \\
\hline 3 & Logout & $\begin{array}{l}\text { Menampil } \\
\text { kan form } \\
\text { logout }\end{array}$ & $\begin{array}{l}\text { Keluar dari } \\
\text { halaman } \\
\text { website }\end{array}$ & $\mathrm{V}$ & \\
\hline
\end{tabular}

\section{Pengujian External}

Pengujian eksternal dilakukan dengan cara menguji program langsung kepada user di instansi yang terdapat pada tabel dibawah ini:

Tabel 3. Hasil pengujian eksternal

\begin{tabular}{|c|c|c|c|c|c|c|c|}
\hline \multirow{4}{*}{ No. } & \multirow[t]{4}{*}{ Pertanyaan } & \multicolumn{6}{|c|}{ Kesesuaian } \\
\hline & & SS & $\mathbf{S}$ & KS & TS & STS & Ket \\
\hline & & \multicolumn{5}{|c|}{ Skor } & \\
\hline & & 5 & 4 & 3 & 2 & 1 & \\
\hline 1 & $\begin{array}{l}\text { Apakah aplikasi e- } \\
\text { village ini mudah } \\
\text { dalam } \\
\text { pengoperasiannya? }\end{array}$ & 2 & 2 & 1 & & & \\
\hline 2 & $\begin{array}{l}\text { Apakah dengan } \\
\text { adanya e-village ini } \\
\text { dapat memudahkan } \\
\text { proses pelayanan } \\
\text { pembuatan surat? }\end{array}$ & 1 & 3 & 1 & & & \\
\hline 3 & $\begin{array}{l}\text { Apakah sistem } \\
\text { informasi ini layak } \\
\text { digunakan? }\end{array}$ & 2 & 3 & & & & \\
\hline
\end{tabular}

\begin{tabular}{clllll}
\hline $4 \quad \begin{array}{l}\text { Apakah semua fungsi } \\
\text { yang terdapat pada } \\
\text { sistem e-village } \\
\text { sudah sesuai dengan } \\
\text { yang diharapkan } \\
\text { kantor desa? }\end{array}$ & & 1 & 3 & 1 \\
\hline $5 \quad \begin{array}{l}\text { Apakah tampilan } \\
\text { atau design aplikasi } \\
\text { sistem e-village ini } \\
\text { sudah menarik? }\end{array}$ & 2 & 1 & 1 & 1 \\
\hline Total & $\mathbf{7}$ & $\mathbf{1 1}$ & $\mathbf{6}$ & $\mathbf{2}$ \\
\hline
\end{tabular}

Berdasarkan pengumpulan hasil responden pada table 3, maka dapat ditentukan skor sebagai berikut:

a. Perolehan skor $=\Sigma$ skor responden

b. Skor hasil pengumpulan data

$=(7 \times 5)+(11 \times 4)+(6 \times 3)+(1 \times 2)$

$=35+44+18+2$

$=99$

c. Jumlah skor ideal diperoleh dari skor tertinggi $x$ jumlah butir soal $x$ jumlah responden $=5 \times 5 \times 5=$ 125.

Rumus Penentuan Skor $=$ (Skor Perolehan / Skor Ideal) $\times 100$. Perhitungan (99 $/ 125) \times 100=79,2$ hasil perhitungan menggunakan metode skala likert didapatkan nilai kelayakan sebesar $79,2 \%$ yang artinya Aplikasi E-village Berbasis Web Menggunakan Framework CodeIgniter di Kantor Desa PesisirBesuki ini berdasarkan kategori kelayakan pada table 2 dapat dikatakan "Sangat Baik" dan layak untuk digunakan oleh staff di kantor desa dan masyarakat desa pesisir untuk sistem permohonan surat.

\section{Penutup}

Berdasarkan penelitian yang telah dilakukan terhadap perancangan sistem dan pembuatan program aplikasi tersebut, maka dapat diambil kesimpulan sebagai berikut:

Telah dihasilkan aplikasi E-village Berbasis Web di Kantor Desa Pesisir Besuki. Aplikasi ini dapat membantu dan mempermudah dalam pelayanan masyarakat yaitu pelayanan pembuatan surat di Kantor Desa Pesisir Besuki. Hal ini dibuktikan dari hasil pengujian eksternal dengan status kelayakan $79,2 \%$. 


\section{Daftar Pustaka}

Anhar, S. (2010). Panduan Menguasai PHP \& MYSQL Secara Otodidak. Jakarta: Mediakita.

Ariyan Zubaidi, R. (2019). Layanan dan Informasi Akademik Berbasis Bot. Jurnal JTIKA , 1-8.

BPS, S. D. (2018). Statistik Telekomunikasi Indonesia 2018. Jakarta: Badan Pusat Statistik.

Fatta, H. A. (2007). Rekayasa Sistem Pengenalan Wajah. Yogyakarta: Andi Offset

Hakim, L. (2019). Sistem Informasi Layanan Desa Berbasis Web Menggunakan PHP dan MYSQL Studi Kasus Kantor Desa Pecalongan Kecamatan Sukosari Bondowoso. Jurnal IImiah Informatika, 4(1), 33-35.

Herlina, V. (2019). Panduan Praktis Mengolah Data Kuesioner Menggunakan SPSS. In Panduan Praktis Mengolah Data Kuesioner Menggunakan SPSS (pp. 5-7). Alex Media Komputindo.

Kurniawan, A., Suhardiyah, M., \& Hidayat, A. N. (2019). Pemanfaatan Teknologi sebagai Media Informasi Masyarakat Desa Karangkuten Kecamatan Gondang Kabupaten Mojokerto. SNHRP, 26-31.

Kusrini, M., \& Andriyanto. (2007). Tuntunan Praktis Membangun Sistem Informasi Akuntansi dengan Visual Basic \& Microsoft SQL Server. Yogyakarta: ANDI OFFCET.

Lubis, A. (2016). Basis Data Dasar. Yogyakarta: deepublish.
Lulu Luciana Putri, M. F. (2019). Sistem Informasi Administrasi Kependudukan Kelurahan. Jurnal Manajemen informatika \& Sistem Informasi, 1-6.

Marimin, M., Hendri Tanjung, M. M., \& Haryo Prabowo, S. M. (2006). Sistem Informasi Manajemen Sumber Daya Manusia. Bogor: Grasindo.

Masdar, S., Asmorowati, S., \& Irianto., J. (2009). Manajemen Sumber Daya Manusia Berbasis Kompetensi Untuk Pelayanan Publik. Surabaya: Airlangga University Press.

Muslihudin, M., \& oktafianto. (2016). Analisis dan Perancangan Sistem Informasi Menggunakan Model Terstruktur dan UML. Yogyakarta: Andi Offset.

Putri, L. L. (2019). Sistem Informasi Administrasi Kependudukan Kelurahan. Jurnal Manajemen informatika \& Sistem Informasi, 1-6.

Sismadi \& Santoso, R. (2018). Sistem Pengolahan Data Penduduk Wilayah Desa Cilebut. Speed - Sentra Penelitian Engineering dan Edukasi, 10(4), 77-83.

Sitorus, L. (2015). Algoritma dan Pemograman. Yogyakarta: Andi Offset.

Supardi, Y., \& Hermawan, A. (n.d.). Semua Bisa Menjadi Programmer Codeigniter basic. Jakarta: Elex Media Komputindo.

Utami, F. H., \& Asnawati. (2015). Rekayasa Perangkat Lunak. Yogyakarta: deepublish 